\title{
Middle Triassic syntectonic sedimentation and volcanic influence in the central part of the External Dinarides, Croatia (Velebit Mts.)
}

\author{
DUJE SMIRČIĆ ${ }^{1}$, DUNJA ALJINOVIĆ ${ }^{1, *}$, UROŠ BARUDŽIJA ${ }^{1}$ \\ and TEA KOLAR-JURKOVŠEK ${ }^{2}$
}

\footnotetext{
1 University of Zagreb, Faculty of Mining, Geology and Petroleum Engineering, Pierottijeva 6, 10000 Zagreb, Croatia

2 Geological Survey of Slovenia, Dimičeva 14, 1000 Ljubljana, Slovenia
}

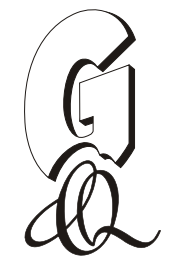

\begin{abstract}
Smirčić, D., Aljinović, D., Barudžija, U., Kolar-Jurkovšek, T., 2020. Middle Triassic syntectonic sedimentation and volcanic influence in the central part of the External Dinarides, Croatia (Velebit Mts.). Geological Quarterly, 64 (1): 220-239, doi: $10.7306 / 9 q .1528$

Middle Triassic deposits in the Velebit Mts. of the External Dinarides in Croatia show strong differentiation of sedimentary environments and facies. In the area of Donje Pazarište, a 90 metre thick section includes six different facies, each with its specific genetic characteristics (Flysch-like Facies; Carbonate Shale Facies; Pyroclastic Density Current Facies; Platy Limestone with Pyroclastics Facies; Limestone Breccia Facies and Slumped Limestones with Pyroclastics and Chert Facies). In the same area, in the nearby Top of Donje Pazarište section, a Pyroclastic Flow Facies was defined, and this was also recognized $\sim 15 \mathrm{~km}$ to south-east, in the area of Brušane Village, in the foothills of Vinac. Throughout the area and section investigated, the effects of intense tectonic and volcanic activity can be traced. The pronounced differences in the facies determined facies are interpreted as consequences of syntectonic and volcanically influenced sedimentation in a graben/half-graben depositional system.
\end{abstract}

Key words: External Dinarides, Velebit Mts., syn-tectonic deposition, Middle Triassic, volcaniclastics, facies.

\section{INTRODUCTION}

In the Middle Triassic the External Dinarides were situated in the western part of the Tethyan Ocean, on the northern coast of the Palaeotethys Ocean, and were influenced by subduction towards the north, related to the opening of the Neotethys that had started in the Permian (Haas et al., 1995; Stampfli and Borel, 2002, 2003; Scotese, 2002; Schmid et al., 2008). Evidence of volcanic activity in the Dinarides, related to Neotethys opening, was present already in the Permian (Hinterlacher-Ravnik, 1965) while the major tectonic and magmatic episodes in the Dinaridic area occurred in the Middle Triassic. The global rifting of the Neotethys greatly influenced the western Tethyan coast and caused a pronounced differentiation of the stable shallow marine environments that persisted throughout the Early Triassic, dominated by mixed carbonate-clastic sedimentation and Early Anisian carbonate platform sedimentation on the southern shelf (Vlahović et al., 2005; Aljinović et al., 2018). Formerly an extensive shallow marine environment, the area of the present day Dinarides came to be composed of uplifted and

\footnotetext{
* Corresponding author, e-mail: dunja.aljinovic@rgn.hr Received: October 29, 2019; accepted: February 11, 2020; first published online: Apri 14, 2020
}

subsiding tectonic blocks. The uplifted blocks were prone to subaerial erosio and dissolution of older carbonate strata, leading to the formation of bauxite (Sokač et al., 1976; Marković, 2002), while the subsiding blocks became marine basins showing characteristics of pelagic sedimentation. Tectonic movements were accompanied by volcanism resulting in the formation of effusive volcanic and volcaniclastic rocks, with geochemical characteristics suggesting magma origin in the subduction zones (Pamić, 1984; Garašić et al., 2006), as also reported from the surrounding area of the Western Tethys (Ferrara and Innocenti, 1974; Castellarin and Rossi, 1981; Crisci et al., 1984; Castellarin et al., 1988; Obenholzner et al., 1991). Observations have been made of various volcanic and volcaniclastic rocks in the Middle Triassic of the Southern Alps (Crisci et al., 1984; Castellarin et al., 1988; Obenholzner et al., 1991), the Internal Dinarides (Pamić, 1984; Dimitrijević, 1997) and the Transdanubian Range and Bükk Mts. in Hungary (Szoldán, 1990; Harangi et al., 1996; Velledits, 2004, 2006; Velledits et al., 2017). Volcanic and volcaniclastic rocks in the Velebit Mts. are locally dominant and exhibit genetic differences. Therefore, their interpretation serves as a useful tool for understanding sedimentation processes in the Middle Triassic. Similar and broadly coeval palaeoenvironment variability, magmatic histories and volcanic-volcaniclastic facies are visible across the surrounding areas of the southern shelf of the Western Tethys (Brandner and Bechstädt, 1970; Velledits, 2004, 2006, 2009; Kóvacs et al., 2010; Celarc et al., 2013; Velledits et al., 2017). 


\section{GEOLOGICAL SETTING}

The Dinarides are a part of Alpine orogenetic belt striking from Slovenia in the north-west to Albania in the south-east. They are usually subdivided into the Internal and External subunits. The belt of high mountain area along the coast of the Adriatic Sea is termed the External Dinarides, while the lower relief part in the north-east is the Internal Dinarides. The External Dinaridic subunit consists mainly of carbonate deposits from Jurassic to Cretaceous in age, deposited at a time when the area existed as a wide carbonate platform (Adriatic Carbonate Platform; Vlahović et al., 2005). The pre-platform deposits, Paleozoic and Triassic strata, crop out along major thrusts and faults or as the cores of anticlines (Herak, 1974; Chorowitz, 1977). Pamić (1984) suggested that these deposits crop out along the edges of the Cenozoic carbonate platform.

The localities investigated are all situated in the Velebit Mts., a dominant tectonic structure of the central part of the External Dinarides, which consists of several overthrusted zones comprising strata ranging from Carboniferous to Eocene in age. The areas investigated areas are located on the NE slope of the central part of the Velebit Mts., near the villages of Donje Pazarište and Brušane (Fig. 1).

The deposits described in this study are a part of the overthrusted zone bordering the Brušane Anticline, that is dissected by two major faults, in the SW and NE (Fig. 1). The strata have typical Dinaridic orientation, striking from NW to SE (Fig. 1). To the south-west, the Paleozoic and Triassic strata are in contact with Jurassic and Eocene deposits, while in the north-east the Middle Triassic strata investigated are bordered by Upper Triassic and Lower Jurassic deposits. Middle Triassic deposits are represented by Anisian to Ladinian carbonates accompanied by clastic, volcaniclastic and volcanic rocks, ranging in age from Early to Late Illyrian (Smirčić et al., 2018). The volcaniclastic and volcanic rocks represent a genetically different unit outcropping between the Middle Triassic carbonates (Fig. 1). In the core of the Middle Triassic succession investigated, two minor domes of olivine basalts were recorded (Sokač et al., 1974; Lugović et al., 1998). On the forest road leading from Popovača Creek to the local topographic high, south-west of the village Donje Pazarište, the section of that name with various deposits, including volcaniclastics, was recorded (the beginning of the section has the coordinates $\left.44^{\circ} 37^{\prime} 39.75^{\prime \prime} \mathrm{N}, 1^{\circ} 08^{\prime} 54.25^{\prime \prime} \mathrm{E}\right)$. In the broader area investigated, in the vicinity of Donje Pazarište and in the same tectonic unit, genetically different volcaniclastic rocks occur. Because of their similar geochemical characteristics they were also investigated and below, as the Top of Donje Pazarište section and the foothills of Vinac (co-ordinates 44 $34^{\circ} 43.20 " \mathrm{~N}$ 15¹5’30.27"E) (Fig. 1).

\section{METHODOLOGY}

Rocks from three localities have been investigated: the Donje Pazarište (DP) section represents an almost continuous $92 \mathrm{~m}$ thick succession of volcaniclastic and sedimentary rocks. Samples were collected for petrographic analysis. The second locality, named Top of Donje Pazarište, shows a distinctive volcaniclastic facies closely related to the DP section. A third locality with exposed rocks has been investigated near Brušane village (foothills of Vinac) and reveals similar petrographic and geochemical features to the volcaniclastics of the Top of Donje Pazarište section. Thin-sections from 138 rock samples were prepared with the standard procedure and stained by Alizarine Red S and K-ferricyanide. For classification of the volcaniclastic rocks, a genetic approach was used, based on their genetic differences. This combines the classification of McPhie et al. (1993) and the term Pyroclastic Density Current as used by DiCapua et al. (2016) for all syn-eruptive deposits directly settled during an eruptive episode by a pyroclastic density current (PDC). This classification includes both volcanic and sedimentary processes and describes their genetic differences and characteristics. Volcanic and volcaniclastic rocks of different facies were selected for further geochemical analysis. The pelitic samples from the DP section were ground to powder and analysed using a Phillips vertical X-ray goniometer (type X'pert) equipped with $\mathrm{Cu}$ tubes and a graphite crystal monochromator. Minerals were identified using PANalytical X'Pert HighScore software with standardized Powder Diffraction Files of the International Centre for Diffraction Data (Newton Square, PA, USA). Volcanic and volcaniclastic samples from all localities investigated were selected for whole rock geochemical analysis. Samples were ground to powder using an agate mill and analysed in the ACME Laboratory, Vancouver, Canada. ICP-ES analysis was used for the determination of major element oxide content and ICP-MS analysis for minor and trace elements.

\section{DONJE PAZARIŠTE SECTION}

The section represents continuous deposition from the Illyrian to the Fassanian (Smirčić et al., 2018). In the upper part of the section an unexposed interval occurs, but despite this the section is considered continuous on the basis of a continuous conodont biostratigraphy (Smirčić et al., 2018). Six facies are recognized (Fig. 2):

\section{FLYSCH-LIKE FACIES (FF)}

The beginning of the section comprises an 18 metre thick interval defined as Flysch-like Facies. The facies consists of brown sandstones and shales (Fig. 3A). The sandstones are feldspathic and lithic greywackes (Fig. 3B), the lithic fragments dominantly being of effusive and intrusive igneous rocks. The sandstone layers are centimetres to decimetres thick and rarely show parallel and cross-lamination or normal grading. Shale layers are homogeneous and thicker (up to a metre) than the sandstones. Continuous transitions from sandstone to shale are common. Gutter casts occur rarely on the soles of the sandstone layers. In the upper part of this interval the sandstones become coarser grained.

XRD analysis determined the predominance of illite-smectite material in the shales. Lithic clasts in the sandstones are of magmatic origin, mostly basaltic or granitic in composition. The sandstones are feldspathic or lithic greywackes with matrix that is exclusively politic, including submicroscopic material.

Facies interpretation: the Flysch-like Facies represents the only dominantly siliciclastic facies in the DP section. These deposits were determined as "flysch-like deposits" by earlier researchers (Sokač et al., 1976) or "Anisian flysch" in other areas of the Dinarides (Dimitrijević, 1997). Sokač et al. (1976) suggested that the siliciclastic material accumulated in a calm low energy marine, possibly reducing, environment, prior to further redeposition by turbidity currents. The apparent lack of pyroclastic material suggests deposition in a time interval without significant volcanic activity (cf. Fisher and Schmincke, 1984; 


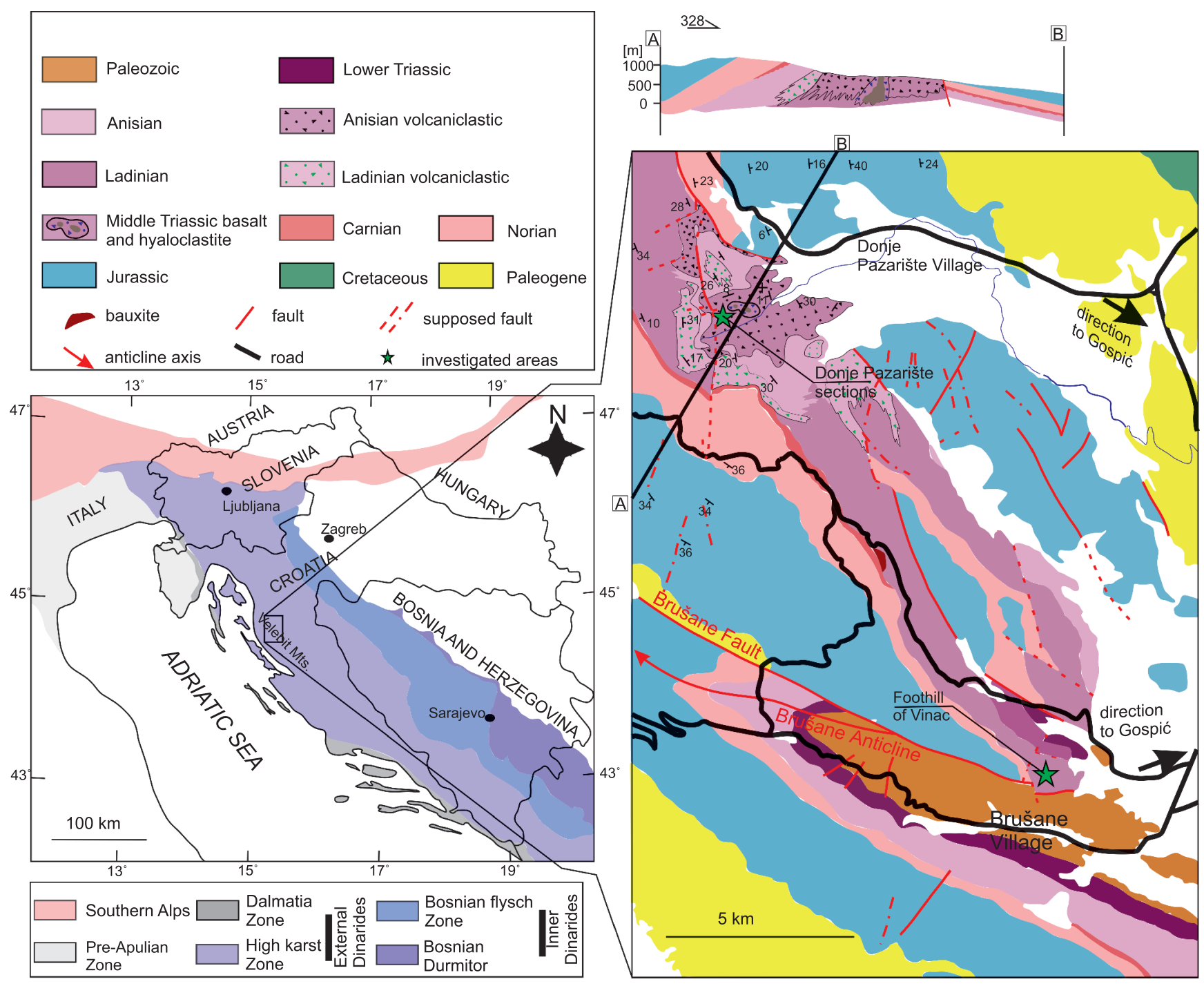

Fig. 1. Regional geotectonical map of the Dinarides and the Alps according to Schmid et al. (2008) and part of the Basic Geological Map 1:100,000 sheet Gospić with a geological profile across the area investigated, modified after Sokač et al. (1974)

Green asterisks mark the localities investigated

McPhie et al., 1993). The predominance of basalt and granite lithoclasts indicates erosion of igneous rocks in the source area. Feldspars from volcanic rocks might have been intensely weathered, causing the accumulation of large amounts of clay.

Interbedding of sandstones and shales, grading, horizontal and cross-lamination in sandstones, together with gradual transitions from sandstone to shale indicate deposition from gravity flows, possibly low-density turbidity currents. Thick homogeneous shale layers apparently represent depositional intervals with weakening gravity currents. The presence of turbidites indicates tractional transport along an underwater slope, and redeposition into deep, possibly suboxic, basinal areas (as stated by Sokač et al., 1976). Persistent bed thickness and uniformly rhythmic sandstone-to-shale changes suggest deposition on the distal part of a submarine fan. Coarsening of the sandstones towards the top of the FF interval may be interpreted as representing shallowing of the environment.

\section{CARBONATE SHALE FACIES (CS)}

The Flysch-like Facies is conformably overlain, with gradual transition, by the Carbonate Shale Facies which forms a homogeneous interval $28 \mathrm{~m}$ thick. The facies is dominated by carbonate shales with beds of homogeneous white to pale yellow, crystaloclastic and altered vitriclastic tuff up to $10 \mathrm{~cm}$ thick. The carbonate-bearing shales contain thin-shelled bivalves and rare ammonoids that enabled determination of the Illyrian age (Smirčić et al., 2018); they are dark grey to black with varying amounts of carbonate and siliciclastic (clayey) component ( 25 to $70 \%$ ), and with generally increasing carbonate content upwards (Fig. $3 \mathrm{C}$ ). The carbonate component is represented dominantly by lime mud with subordinate thin-shelled bivalve fragments, calcitized radiolarians and rare crinoid fragments (Fig. 3D). In places, the shales include a small amount of silt-sized quartz and feldspar grains or clasts of 


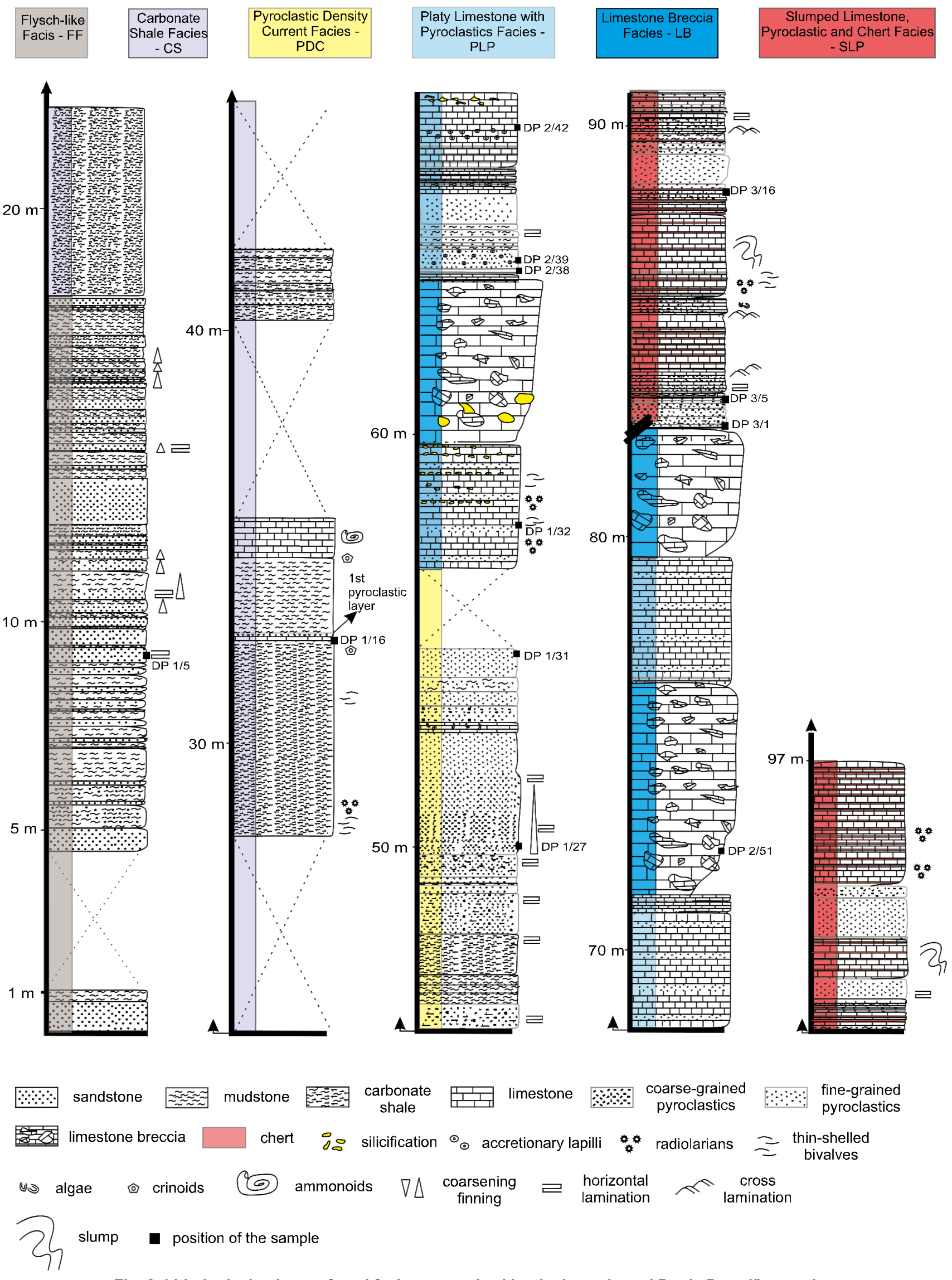

Fig. 2. Lithological column of, and facies recognized in, the investigated Donje Pazarište section

The column represents time interval ranging from the Illyrian to the Fassanian (modified after Smirčić et al., 2018) 

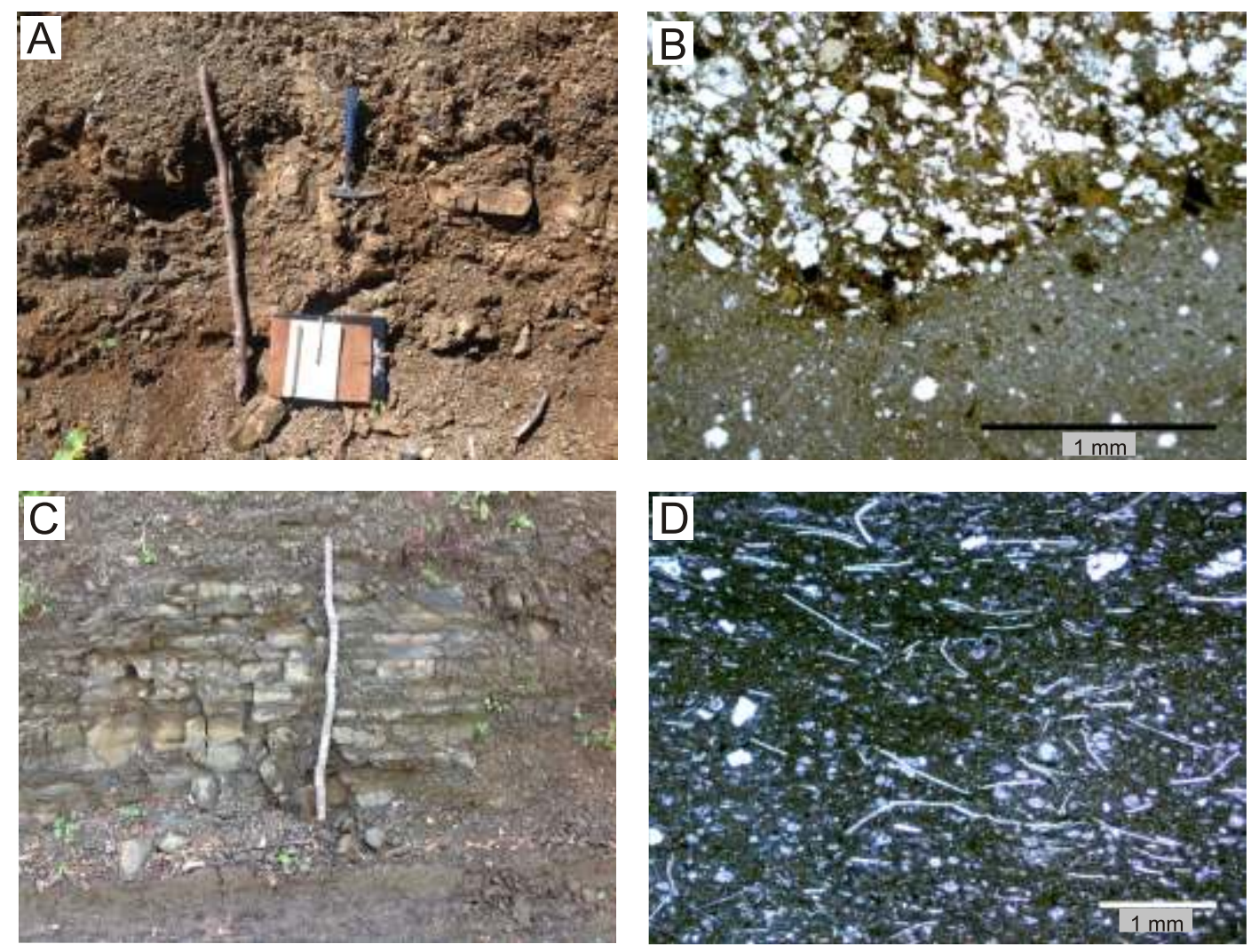

Fig. 3. Field photographs of the facies determined in the Donje Pazarište section and accompanying microphotographs of the specific rock types

A - Flysch-like Facies consists of brown shales interbedded with dm-thick lithic and feldspathic greywackes; B microphotograph showing contact between shale and feldspathic greywacke (sample DP-1/5); C - field photograph of the Carbonate Shale Facies composed dominantly of grey carbonate shales (stick for scale $1 \mathrm{~m}$ ); D - microphotograph of carbonate shale in CS (sample DP-1/16); note the abundance of thin-shelled bivalves, radiolarians and some feldspar grains in a lime-pelitic matrix

hyaline volcanic origin. Occasionally, the lime mud contains star-, needle- or irregularly shaped molds that resemble glass shards.

The crystaloclastic tuffs consist of hipidiomorphic to idiomorphic feldspar crystaloclasts embedded within lime mud. Rare altered vitriclastic tuffs have fine ash vitriclastic particles (altered to microcrystalline quartz), altered plagioclase crystaloclasts and rare shard-shaped molds.

Facies interpretation: the continous transition from the Flysch-like Facies to the Carbonate Shale Facies indicates decreasing siliciclastic input and a subsequent prevalence of carbonate sedimentation in marine conditions. The presence of thin-shelled bivalves, radiolarians, crinoids and ammonoids in the carbonate shales indicates an unrestricted, deep marine pelagic environment. Thin interlayers of pyroclastic deposits within the carbonate shale suggests a commencement of volcanic activity with brief volcanic eruptions and limited availability of volcaniclastic material. Thin vitriclastic and crystaloclastic tuff layers are interpreted as air- to water-fall deposits, settled from suspension in deep/pelagic marine areas above the CCD.

\section{PYROCLASTIC DENSITY CURRENT FACIES (PDC)}

The 28 metre thick CS is conformably overlain by a 12 metre thick interval of the Pyroclastic Density Current Facies. This facies contains centimetre- to metre-thick yellow crystaloclastic (Fig. 4A) and fine-grained pale green vitriclastic units. Some units show cross- and/or horizontal lamination. The transition from crystaloclastic to vitriclastic units is mostly continuous. Crystaloclastic units dominantly contain well-sorted coarse sand-sized feldspar crystaloclasts and subordinate lithic fragments, biotite crystaloclasts and scoria fragments. Feldspars are predominantly euhedral plagioclase, with subordinate sanidine (Fig. 4B). Three types of lithic fragments are determined: hyaline, andesite and rare limestone fragments, some with fossil algae. Exceptionally rare accretionary lapilli were observed, spherical, consisting of microcrystalline quartz cores and fine ash rims.

Pale yellow to pale green vitriclastic units of the PDC consist of homogeneous (rarely laminated) fine-grained glass shards, 

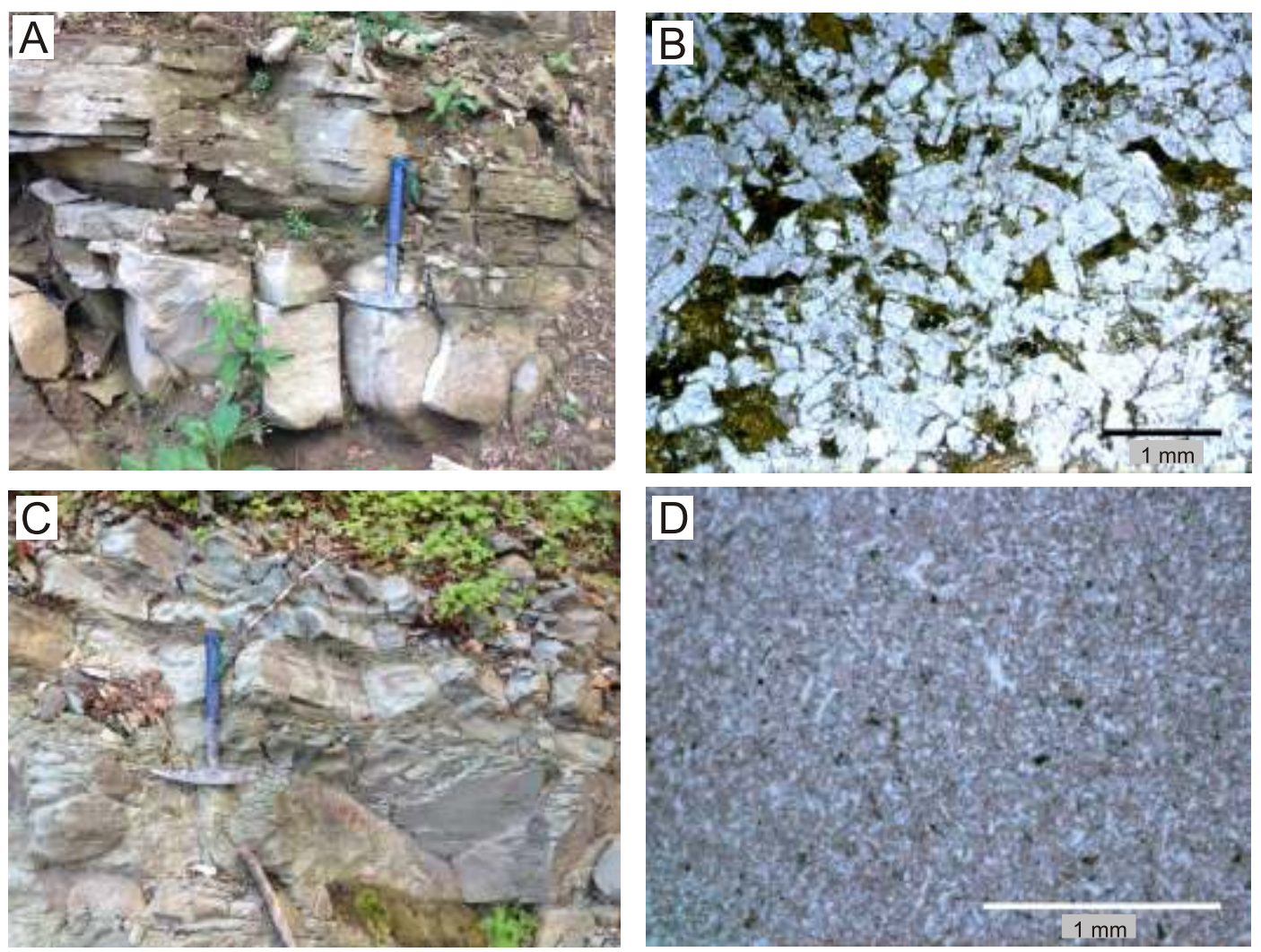

Fig. 4. Pyroclastic Density Current Facies composed of two distinctively segregated units; crystaloclastic coarse-grained beds with cross- and horizontal lamination and beds composed exclusively of fine ash size glass shards

A - a metre-thick crystaloclastic unit with horizontal lamination of the PDC (lower part of the photograph); B a microphotograph of the crystaloclastic unit of the PDC composed of euhedral, unaltered plagioclase crystals (sample DP-1/27); C - field photograph of the homogeneous pale green vitriclastic unit of the PDC; $\mathbf{D}$ - sample DP-1/31 of the PDC predominantely composed of glass shards cemented with sparry calcite

rare pumice fragments and crystaloclasts (Fig. 4C). Glass shards exhibit different shapes (X, Y, curviplanar, platy) and are devitrified and altered to chlorite, calcite and opaque minerals. Crystaloclasts are represented by plagioclase, sanidine and quartz. In places, the vitriclastic material is cemented with sparry calcite (Fig. 4D).

Facies interpretation: the PDC reflects intensifying volcanic activity. The differences in clast size ranging from lapilli to fine ash, the presence of idiomorphic (angular) crystaloclasts, as well as the monomictic composition of crystaloclastic units indicate proximity to volcanic centres. The presence of accretionary lapilli suggests its primary formation via subaerial volcanic eruption. As interpreted by Fisher and Schmincke (1984), Boulter (1987), McPhie et al. (1993), Sigurdsson (2007) and Cunningham and Beard (2014), accretionary lapilli are generated by accumulation of fine volcanic ash in the outer zone of a pyroclastic cloud, and the same authors state that primary lithification of lapilli occurs on land. Therefore, their presence in marine strata suggests their resedimentation. The presence of pyroclastics with a calcite cement/matrix and the contacts of this facies with carbonate deposits (Carbonate Shale Facies at the base, and Platy Limestone with Pyroclastics Facies at the top) imply that the deposition took place in a marine environment. Cross- and horizontal lamination in crystaloclastic units indicates that the volcaniclastic detritus was subjected to tractional transport. The presence of cross-lamination that transforms upwards to plane parallel lamination, large amounts of hipidiomorphic plagioclase, the presence of pumice fragments and the superpositional transition from crystaloclastic to vitriclastic units, suggests interpretion in terms of resedimentation of pyroclastic material, possibly by gravity currents. The clear segregation of crystaloclastic (coarser - coarse ash to lapilli) from vitriclastic (finer - medium to very fine ash) material indicates separation in a gravity (turbidity) flow, as pyroclastic turbidites (Bull and Cas, 1991; Sulpizio et al., 2014; Di Capua et al., 2016; Di Capua and Groppelli, 2016). Horizontal lamination in the vitriclastic units, composed of fine ash, indicates deposition by suspension settling from dilute low-density turbidites. Therefore, it is assumed that the primary accumulation of erupted pyroclastic material took place on land, or in a shallow marine environment, after which the pyroclastic material was almost immediately resedimented to deeper parts of the sedimentary basin by density currents. Thus, the term Pyroclastic Density Current is used to describe these pyroclastic deposits (Sulpizio et al., 2014; Di Capua et al., 2016). The shapes of the glass shards (bubble-wall, $X$ and $Y$ - according to Heiken, 1974; Izett, 1981) and the presence of scoria fragments indicate a large amount of volatiles in the volcanic system, that increased explosivity, probably due to water inflow to the volcanic system, either on land or in the shallow water marine areas, near to where rocks of the PDC were finally deposited (Sheridan and Wohletz, 1981; Wohletz, 1983, 1986; Kokelaar, 1986; Valentine et al., 2014; Di Capua et al., 2016; Di Capua and Goroppelli, 2016). 
PLATY LIMESTONE

WITH PYROCLASTICS FACIES (PLP)

A short (1.5 m thick) unexposed interval divides the deposition of the PLP from the underlying Pyroclastic Density Current Facies. The facies consists of moderately thick grey platy limestone beds interbedded with pyroclastic deposits. The limestones are usually intensely silicified (Fig. 5A), locally in the form of irregular nodules. Pyroclastic material regularly occurs in the limestones (up to 10\%). Various types of limestone are present:

- wackestones with pelagic biota consisting of lime mud with thin-shelled bivalves and radiolarians (some bioclasts are silicified) (Fig. 5B);

- packstones with pelagic and shallow-water biotas dominated by tightly packed thin-shelled bivalves, radiolarians and crinoids, and also fragments of shallow-water fossils (algae and foraminifera) and clasts of pure micrite or micrite with fine feldspar crystaloclasts (Fig. 5C);

- lithoclastic limestones (sensu Flügel, 2004) containing lithoclasts of different shallow-water limestone types and scarce pyroclastic material (Fig. 5D).

Limestone debris in the lithoclastic limestones is characterized by the prevalence of poorly sorted, in places graded sand-sized carbonate clasts, containing fossils of algae, fora- minifera, bivalves and rare oncoids. The clasts are cemented with mosaic sparry calcite. The limestone beds are organized in $\mathrm{dm}$-scale cycles where wackestones with pelagic biota are overlain by packstones with mixed biota, followed by lithoclastic limestone.

The pyroclastic layers are up to $5 \mathrm{~cm}$ thick, and commonly wavy or irregularly bedded. The pyroclastic material occurs as vitri- and crystaloclastic layers, some of which contain significant amounts of accretionary lapilli (Fig. 6A).

Facies interpretation: the fossil associations in the limestone indicate deposition in a marine environment, while the pyroclastic material continues to have characteristics of subaerial explosive eruptions (large amounts of glass shards and accretionary lapilli). Different limestone types suggest deposition in environments with pronounced bathymetric variations, the depositional depth possibly changing due to tectonic activity. The presence of thin-shelled bivalves, radiolarians and crinoids in the wackestones, together with pelagic biota, indicates an open, deep marine to pelagic environment (Flügel, 2004) while lime mud was slowly deposited in low energy conditions, without the influence of marine currents or waves.

Packstones in this facies show mixing of pelagic biota (thin-shelled bivalves and radiolarians) with shallow marine biota (algae and foraminifera). Micritic clasts, containing fine crystaloclastic feldspars, likely formed in very shallow marine areas influenced by air-fall pyroclastic material. Pyroclastic ma-
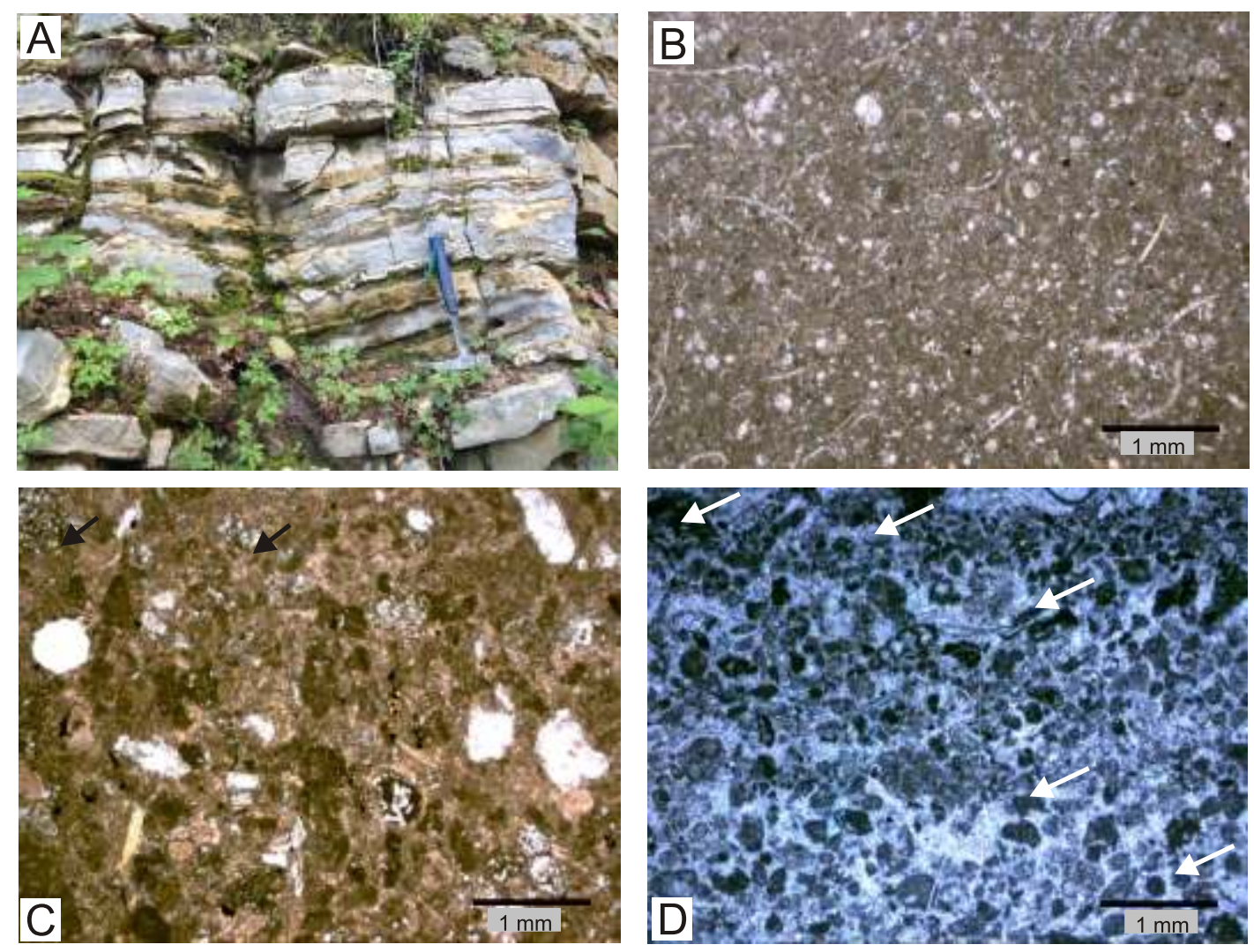

Fig. 5. Photographs of the Platy Limestone with Pyroclastics Facies

A - field photograph of the PLP; grey limestone beds (tens of centimetres thick) are interbedded with yellowish pyroclastic deposits; irregular yellow nodules are considered diagenetic; B - biomicrite/wackestone limestone variety contains radiolarians and thin-shelled bivalves (sample DP-1/32); $\mathbf{C}$ - packstone variety of the PLP consists of intraclasts and fossils; note the specific intraclast type containing small plagioclase crystals (arrows) (sample DP-2/38); D - lithoclastic limestone consists of intraclasts and shallow marine benthic organisms (foraminifers), PLP (sample DP-2/42) 

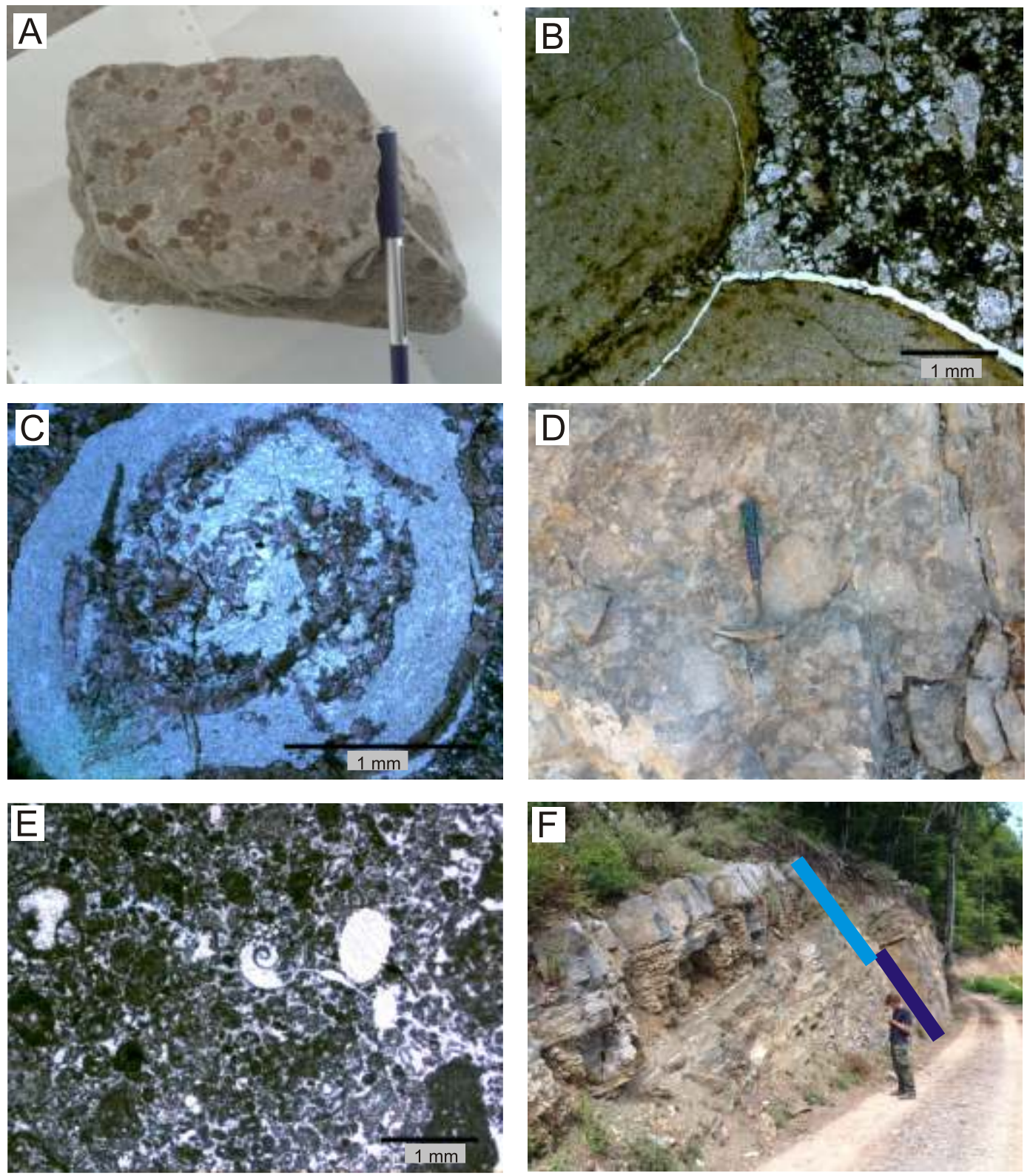

Fig. 6. Field photographs and microphotographs of the facies determined

A - a pyroclastic bed rich in cm-scale accretionary lapilli (upper bedding plane - sample DP-LAP; $\mathbf{B}$ - microphotograph of the sample DP-LAP, showing contact of two accretionary lapilli; lapilli are composed of thin concentrical laminae of fine ash, devitrified to chlorite; matrix between the lapilli is composed of plagioclase crystals and fine vitric material; C - accretionary lapilli found in the limestone; the cores of the lapilli are calcitized whereas the rims are composed of fine ash, devitrified to microcrystalline quartz (sample DP-2/39); $\mathbf{D}$ - field photograph of the LB; note the poor sorting of the clasts found in the dark grey matrix consisting of lime mud and fragmented fossils; $\mathbf{E}$ - sample DP-2/51 of the LB containing variously sized clasts of biomicritic and micritic limestones; benthic foraminifers, crinoids and ammonoids are also present; $\mathbf{F}$ - metre-scale depositional cycles consist of limestone breccia (dark blue bar), overlain by pyroclastic layers and platy limestones with pyroclastics (light blue bar); there are three such alternations in the upper part of the Donje Pazarište section; field photograph

terial was probably deposited in shallow marine areas where it was incorporated into lime mud and then resedimented into a somewhat deeper environment as clasts. The resedimentation occurred due to marine currents or waves that also moved skeletal clasts of shallow marine organisms into deeper areas.

The lithoclastic limestones, usually overlying wackestones and packstones, signify intense resedimentation from shallow areas, possibly by turbidite-like currents, and therefore have the characteristics of allodapic limestones. The different composition of the lithoclasts indicates that they were formed in shallow marine areas and subsequently resedimented. Sparry calcitic cements in the lithoclastic limestone indicate higher energy conditions where lime mud was unable to accumulate.

The presence of pyroclastic material indicates volcanic influence throughout the limestone deposition. Distinct pyroclastic layers indicate eruptions, and air-transported material. 
The presence of accretionary lapilli suggests eruptions in subaerial conditions and the formation of lapilli in subaerial volcanic clouds by agglutination of fine ash particles (Soh et al., 1989; Ayres et al., 1991; Marci et al., 1991; McPhie et al., 1993). These were primarily deposited on land where they became completely lithified. After their primary deposition and complete lithification they were resedimented to deeper marine, pelagic areas and may be found even in the limestones (Fig. 6B, C). The size of the lapilli and their complete lithification prevented their disintegration during transport and enabled accumulation in deep water (Boulter, 1987; Cunningham and Beard, 2014). The dominance of crystaloclastic or vitriclastic fragments in individual layers can be interpreted as segregation of the pyroclastic material through water-settled air-fall. This evidence supports the hypothesis that the pyroclastic material was wind-blown and transported in the eruption cloud from a continent to a marine environment, and resedimented from shallower to somewhat deeper sea.

\section{LIMESTONE BRECCIA FACIES (LB)}

The LB repeatedly occurs in the upper part of the section forming 3-6 metre thick intervals (Fig. 2). The limestone breccias consist mainly of angular unsorted limestone clasts $(\mathrm{cm}$ - to m-scale) incorporated in a matrix of finer fragments (Fig. 6D). Grading can be observed locally, and clast roundness and sphericity vary. The clasts represent various limestone types, most commonly biomicritic and intrasparitic, while the rarest are oncomicrites. The skeletal fragments correspond to shallow marine organisms. Some limestone clasts show dissolution cavities. Between breccia clasts, a somewhat darker matrix containing ammonoid, crinoid and thin-shelled bivalve debris is distinguished (Fig. 6E). Three massive breccia beds appear in the upper part of the section, as intervals within the Platy Limestone with Pyroclastics Facies (Fig. 6F).

Facies interpretation: the unsorted breccia fragments and matrix-supported structure suggest the deposition of the breccia by debris flows. The limestone clasts correspond to shallow-water limestones (with algae, oncoids, and dissolution cavities) and primary deposition in a shallow marine setting (platform/ramp), possibly on uplifted tectonic blocks. Strong tectonic activity might have caused fragmentation of the shallow-water limestones and redeposition by debris flows to a deep basin (associated with subsiding blocks). The presence of thin-shelled bivalves and crinoids in the breccia matrix shows that deposition occurred in a deep marine, pelagic environment. The tectonic influence can be envisaged as uplifting or subsiding blocks, possibly accompanied by the volcanic activity. Periods of active tectonics could have triggered avalanches of the limestone clasts, now recognized as breccias. Deposition of limestones within the PLP interspersed with the breccias indicates tectonic cessation at least three times, in the upper part of the section. The lithoclastic limestones from the PLP could have formed similarly to the breccia layer, by deposition from debris flows which became diluted and enriched in finer particles.

\section{SLUMPED LIMESTONE WITH PYROCLASTICS AND CHERT FACIES (SLP)}

The top of the recorded section consists of a 15.6 metre thick Slumped Limestone with Pyroclastics and Chert Facies (Fig. 7A). In the lower interval of the facies coarser grained pyroclastic material prevails, while in the upper part it becomes fine-grained and less common.

The grey limestone beds of this unit range in thickness from 2 to $20 \mathrm{~cm}$ and are interbedded with vitriclastic and rarely crystaloclastic tuffs and microcrystalline cherts. Thicker limestone beds show trough cross-bedding (Fig. 7B), visible due to differences in the amount and/or grain size of the pyroclastic component (from ash to lapilli size). Three limestone types are distinguished:

1 - wackestone with pelagic biota;

2 - packstone with shallow marine and pelagic biota;

3 - lithoclastic limestones (sensu Flügel, 2004).

The limestone composition is similar as in the PLP, differing only in the significantly increased content of radiolarians.

The pyroclastic deposits (tuffs) are horizontally and crosslaminated. As in the limestones, lamination is visible due to the presence of different amounts of vitriclastic to crystaloclastic material and differences in grain size of the laminae (Fig. 7C). Compared with the previously described facies: the amount of pumice fragments and quartz crystaloclasts is significantly increased (Fig. 7D).

The crystaloclastic tuffs consist predominantly of crystals with a small amount of vitriclasts. Among crystals, plagioclase prevails while alkali feldspar and quartz are present in lesser amounts. Plagioclase and alkali feldspar are usually hipidiomorphic, ranging in size from medium- to coarse-grained sand. Quartz crystals are mostly anhedral, with oval, spherical and elliptical cavities in the centre. Pumice fragments are elongated to platy and devitrified to micro- and cryptocrystalline quartz aggregates. Crystals are supported by fine ash, lime mud (Fig. 7E) or sparry calcite. The vitriclastic tuffs are composed of glass shards of various shapes, most commonly $X, Y$ and bubble-wall shards. Sporadically, very fine ash with irregular shapes is a dominant component.

The cherts are homogeneous, and predominantly composed of microcrystalline quartz. Occasionally, radiolarians can be observed. Gradual transitions between all lithotypes described were observed.

Facies interpretation: abundant radiolarians found in the rocks of this facies indicate deposition in an open marine pelagic environment. At the same time, pelagic deposition was influenced by volcanic activitiy documented by interlayers of tuff. The presence of pyroclastic particles in the limestone beds suggests their fall through air and water. Radiolaria-bearing limestones and cherts represent the background sediment of the pelagic environment. Slump structures (Fig. 7B), characteristic of this facies, indicate plastic rock deformation on an unstable basin slope that steepened due to tectonic activity, perhaps faulting, the formation of a graben-like deep marine depositional environment being inferred. All rock types found in this facies were slumped, suggesting their displacement down the steep slope. Accumulated lime mud indicates deposition of material from suspension, below storm wave base. The three limestone types recognized (the same as in the Platy Limestone with Pyroclastics Facies) indicate deposition in low energy deep marine basin (wackestone with pelagic biota) interrupted by the input of detritus from shallow marine areas (packstone with shallow and pelagic biota and lithoclastic limestones).

The presence of pyroclastic debris indicates constant volcanic activity. The crystaloclastic tuffs are enriched in quartz, albite, alkali feldspars and pumice, indicating an acidic magma composition. The origin of the pyroclastic material implies powerful eruptions on land and subsequent air-fall sedimentation or instant resedimentation processes. Quartz crystals with oval cavities indicate that volatile-rich eruptions produced the pyro- 

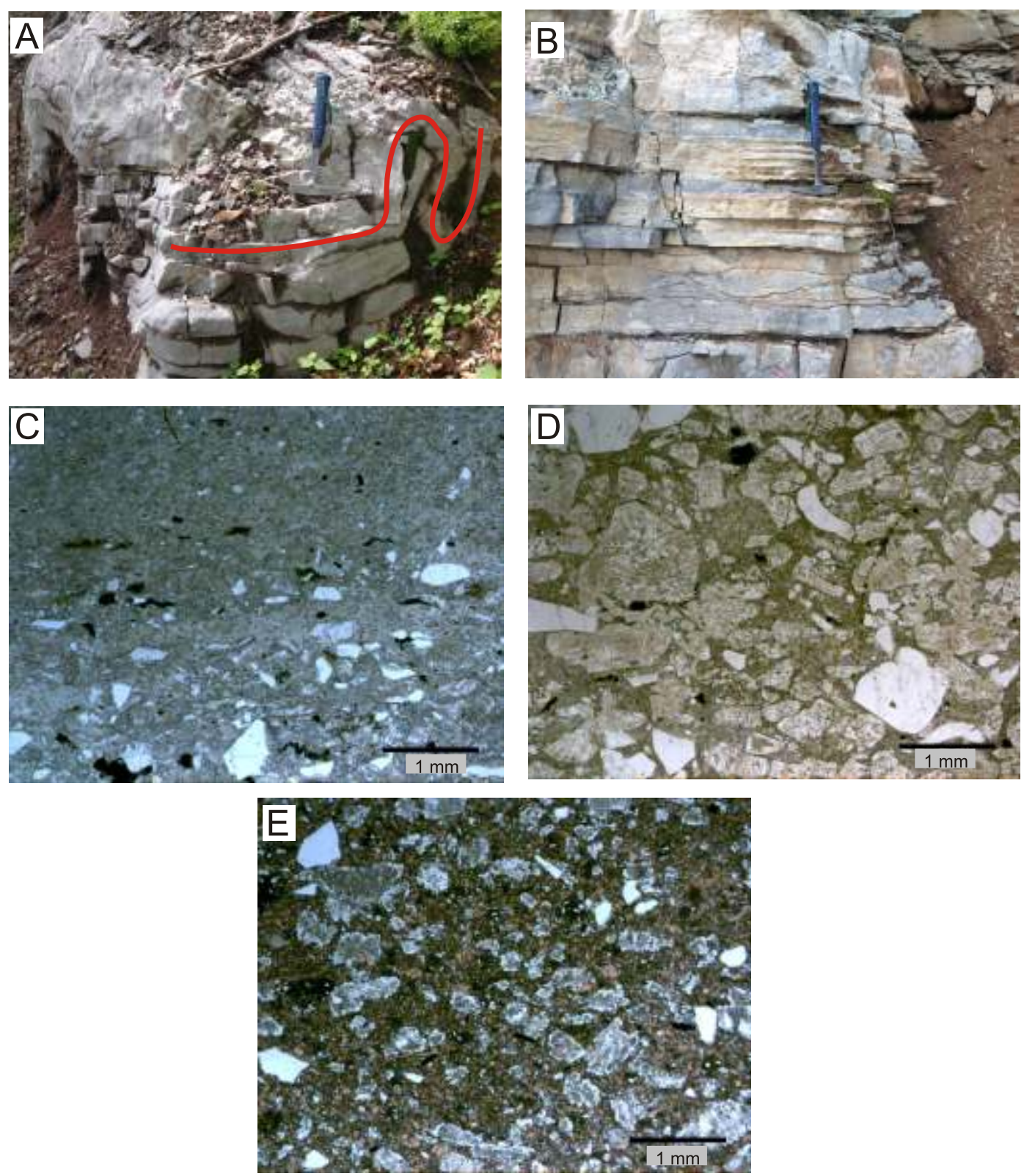

Fig. 7. Field and microphotographs of the rocks in the Slumped Limestone with Pyroclastics and Chert Facies (SLP)

A - a peculiar feature of the SLP is the occurrence of a slump structure as marked in the photograph (red line); $\mathbf{B}$ - field photograph of the SLP; decimetre-thick grey limestones are interbedded with $\mathrm{cm}$-scale yellowish pyroclastic and red chert layers; note the wavy bedding in the lower part of the photograph, as well as the cross-lamination in the $30 \mathrm{~cm}$ thick limestone layer with pyroclastic debris in the upper part of the photograph; C - sample DP-3/5 exhibiting the contact of crystaloclastic and vitriclastic grains, occasionally seen as faint lamination; note that the vitric material is entirely altered and devitrified to microcrystalline quartz, making it difficult to distinguish from microcrystalline cherts; $\mathbf{D}$ - crystaloclastic tuff of the SLP, composed of feldspar and quartz crystals and glass shards (sample DP-3/1); E - altered feldspar crystals in limestone of the SLP, as evidence of pyroclastic activity during deposition of carbonates in the environment (sample DP-3/16)

clastic material (McPhie et al., 1993) and mixing of this with limestones suggests their final deposition in the marine area. The horizontal lamination in the vitriclastic tuffs that are composed predominantly of ash particles, interlayered with crystaloclastic tuff laminae and cherts (Fig. 7E), indicates slow suspension-settling in low energy marine conditions (pelagic deep marine), while the cross- and horizontal-laminated tuffs and lithoclastic limestones indicate possible resedimentation by gravity currents and tractional transport. Texturally unmodified crystals and the absence of epiclastic material in the crystaloclastic tuffs support the hypothesis of syneruptive resedimentation of pyroclastic material.

Cherts lacking radiolarians indicate a different genesis. With the assumption of constant volcanic eruptions, the accumulation of volcanic ash particles is possible here. Since volcanic ash is very reactive, high silica concentrations can be present in 
the environment. As volcanic ash is dissolved, its primary characteristics are destroyed and a colloidal $\mathrm{SiO}_{2}$ component is precipitated in a marine environment as interlayers between the carbonate and pyroclastic beds. Cherts that contain poorly preserved radiolarian tests signify the influence of volcanism and an increased abundance of radiolarians in the pelagic environment (Vishnevskaya, 1996; Shi et al., 2016; Wang et al., 2019).

\section{TOP OF DONJE PAZARIŠTE SECTION}

\section{PYROCLASTIC FLOW FACIES (PF)}

In the vicinity of the DP section, after $\sim 50 \mathrm{~m}$ of an exposed interval, pyroclastic rocks of another facies crop out. This facies was investigated at the Top of DP section and enables clearer insight into the volcanic/tectonic evolution of the area. It was determined as Pyroclastic Flow Facies, comprising white, grey and pale red rocks with clastic structure. Imbrication of elongated pumice fragments - fiamme - can be observed in some parts of the exposure. Dark, oval, elliptical forms resembling macroperlitic texture were observed (Yamagashi and Goto, 1992). Contact of the rocks sampled with the surrounding lithologies is not exposed, but laterally, massive grey limestones and limestone breccias with a red matrix occur. This pyroclastic facies is composed of crystaloclastic and vitriclastic grains, with a variable ratio between these two components. Vitriclastic material is present in the form of glass shards and pumice fragments. Variously shaped glass shards occur (platy, curviplanar, $\mathrm{X}$ and $\mathrm{Y}$ shaped, bubble-wall). They are devitrified and altered. Finer shards are composed of microcrystalline quartz, while coarser shards are composed of mosaic quartz and albite. Micropetrographic analysis shows that the dark oval and elliptical shapes represent glass shards devitrified to opaque minerals (Fig. 8A). As can be seen in Figure 8B, pumice fragments are elongated, up to $2 \mathrm{~mm}$ in size, and occasionally have central large cavities, possibly lithophysae (Ross and Smith, 1955; McPhie et al., 1993; Sigurdsson, 2007). Pumice fragments are often plastically deformed in contacts with crystals (Fig. 8B). The most common crystals are quartz and feldspars. Quartz crystals vary in size and are usually rounded, with cavities in the center. Feldspars are dominated by albite $(\sim 80 \%)$, and to a lesser extent K-feldspar. They are usually subhedral and fractured. Thin irregular, wavy lamination of densely-compacted vitroclastic material can be seen, indicating flow of pyroclastic material and in places even welding.

\section{BRUŠANE SECTION (FOOTHILLS OF VINAC)}

In the foothills of Vinac Hill, near Brušane village, 20 km from the DP section, an exposure of pyroclastic rocks (Fig. 8C) occurs in immediate contact with Ladinian diploporan limestone (according to Salopek, 1942). There are obvious similarities with the PF from the Top of DP section and therefore this occurrence was also sampled and analysed.

The pyroclastic rocks are grey-green with an apparently coherent texture (Fig $8 \mathrm{C}$ ). The rocks are composed of crystals and pumice fragments, in almost equal amounts, with subordinate glass shards. The crystals are predominantely albite of hypidio- morphic shape, and irregular quartz with spheroidal cavities. Some quartz crystals show resorption rims. Crystals are often fractured with jig-saw fitting between them. The pumice fragments are vesicular, irregular, discoidal and elongated. Usually, they are of lapilli size (>2 mm; Fig. 8D). Between the clasts, glass shards of curviplanar, elongated, $X$ and $Y$ shapes prevail. Pumice fragments and glass shards are often plastically deformed in contacts with crystals. Also, weak imbrication of elongated clasts, especially pumice fragments, can be observed (Fig. 8D). The PF in the DP area is very similar to this one observed in the foothills of Vinac near Brušane Village. The only difference is the absence of the oval and elliptical pattern of the opaque glass shards in the Vinac samples. Therefore, these rocks were also determined as Pyroclastic Flow Facies.

The limestones adjoining the pyroclastic rocks are white to grey intensively silicified bioclastic packstones to floatstones and intraformational limestone breccias (Fig. 8E, F). Bioclastic debris in packstone/floatstone varieties consists mostly of algae, with less common foraminifera. The limestone breccias are composed of white to grey limestone clasts from 2 to $6 \mathrm{~cm}$ in size, derived from bioclastic packstones/floatstones and laminated stromatolites, tightly packed, the $\mathrm{mm}$-scale spaces between them being filled with reddish matrix.

Facies interpretation: the Pyroclastic Flow Facies is determined as dacitic in composition. Crystals of albite and quartz dominate, suggesting origin from acidic volcanic eruptions. Glass shards of $X$ and $Y$ shape and bubble-wall shards as well as the large amount of pumice fragments suggest derivation from acidic, volatile-rich magma. The imbrication of elongated clasts, fiamme structure and plastic deformation of pumice fragments in contact with crystals and jig-saw fit crystal structure implies origin from pyroclastic flow (McPhie et al., 1993). The tight compaction of the glass shards, ductile deformation of pumice fragments around the crystals, as well as the presence of quartz crystals with resorption rims, all indicate material still hot during emplacement. The oval/rounded pattern of glass shards altered to opaque mineral aggregates can be interpreted as alteration zones, formed by hydration of glass shards. This pattern resembles a macroperlitic texture. The peculiar perlitic texture is formed by the hydration of the deposits in the later stages of cooling (Allen, 1988; Yamagashi and Goto, 1992). The bulk pyroclastic material was transported in a pyroclastic flow and emplaced probably in a shallow marine area, as suggested by the presence of algal limestones and limestone breccias with a red matrix, in direct contact or in the vicinity. After deposition, the material remained warm for a certain period of time, and was hydrated in its late cooling stage thus forming the dark pattern interpreted as macroperlitic texture. The hydration could have been caused by the contact with sea water. The sea level oscillation and subaerial exposure due to tectonic activity was interpreted, in the described sections of Donje Pazarište, in terms of the PLP, LB and SLP. Taking this into account, the emplacement of warm/hot pyroclastic flow deposits into a shallow marine environment seems plausible.

The same facies characteristics (Pyroclastic Flow Facies) were determined near Brušane, in the foothills of Vinac. Therefore, their similar genesis is supposed. Mineralogical similarities, composition, and similarities of REE concentrations (Smirčić, 2017) allows the correlation of these deposits with the same facies at the Top of DP section. The only difference is the lack of oval/round alteration patterns that can be interpreted as reflecting no hydration of the deposits in the Brušane area. 

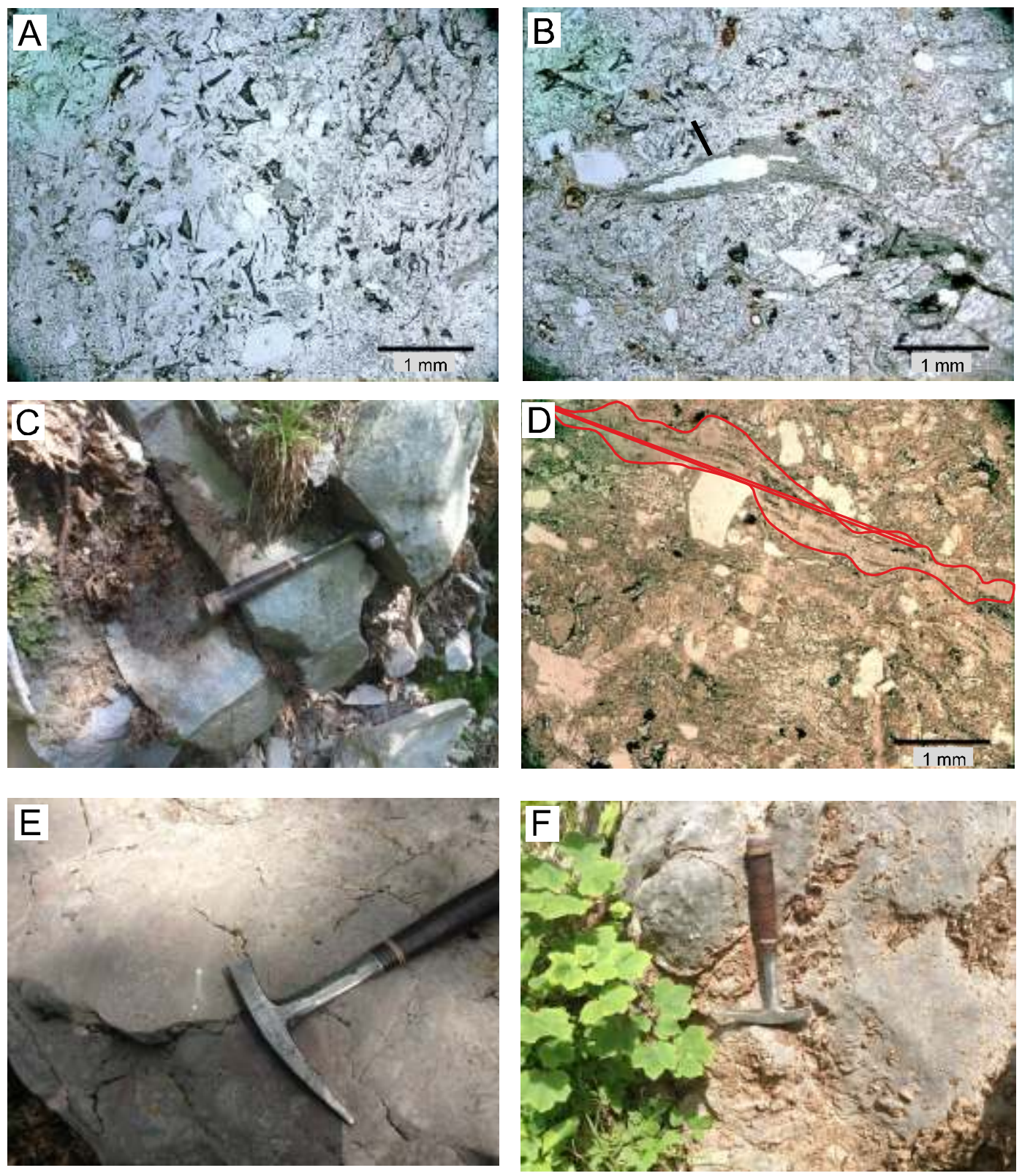

Fig. 8. Photographs and microphotographs of the Pyroclastic Flow Facies

A - microphotograph of the DP-IGB 2 sample from the PF of the Top of DP section. Glass shards are devitrified to opaque minerals, due to fluid circulation causing chemical alteration; $\mathbf{B}$ - microphotograph of the sample DP-IGB 4 with quartz and feldspar crystals and pumice fragments with cavities (arrowed); C - PF in the foothills of Vinac; note the joints in the pyroclastic deposit perpendicular to the orientation of the hammer; $\mathbf{D}$ - microphotograph of sample VI-8 showing elongated pumice fragments aligned as fiamme indicating their flow genesis (pumice fragment is outlined by the red line in the microphotograph); $\mathbf{E}$ - intraformational limestone breccias with reddish matrix are exposed near the rocks of the PF; $\mathbf{F}$ - pronounced silicification of diploporan limestone caused by direct contact with pyroclastic flow; foothills of Vinac

\section{DISCUSSION}

The variety of sedimentary and volcaniclastic facies described in the DP section and nearby exposures of volcaniclastic rocks is related to a volcanic activity taking place in the External Dinaride during the Upper Anisian (Illyrian). The area was characterized by both deep and shallow marine realms, interpreted as a consequence of strong tectonic activity (likely block faulting) accompanied by volcanism. The characteristics of the rocks investigated, especially the volcaniclastic rocks, also indicate a variable genesis. Facies were defined on the basis of their macro- and micropetrographic properties, their position within the succession, as well as their mineralogical and geochemical composition (major and trace elements). The section recorded in the area of Donje Pazarište shows characteristics of sedimentation in a deep marine (pelagic) environment. Near the section recorded, Sokač et al. (1976) reported Middle 
Triassic olivine pillow basalts, also suggesting a deep marine realm. Geochemical characteristics of those basalts (regarding trace elements) show a strong positive geochemical correlation with the pyroclastic rocks from the DP section, and the Top of DP section and foothills of Vinac, near Brušane (Lugović et al., 1998; Smirčić, 2017). Although the strict age of the basalts has not been determined it is assumed that these, as well as the pyroclastic deposits described, represent contemporaneous magmatic activity similar to those ascribed to rifting models in modern and ancient marine realms with related subaerial terrestrial explosive counterparts producing pyroclastic material (Ellis and King, 1991; Jackson et al., 2008; Hnylko et al., 2015). Large pyroclastic eruptions may have been located las far as tens of kilometres away, on land or in shallow sea. Pyroclastic material in the section indicates volatile-rich eruptions. Lapilli and lapilli fragments found in the PLP and SLP show characteristics of terrestrial eruptions or at least primary sedimentation by air-fall on land and subsequent resedimentation in a marine area. The volatile content of the erupted magma may have been increased due to influx of sea water into the magma chamber through fractured crustal rocks. Thus, the volcanic vents may have been situated near shore or in shallow marine areas as inferred for the pyroclastic deposits in DP section (from PDC, PLP and SLP), Top of DP section and Brušane section (PF).

The change in compostion of the pyroclastic material throughout the section, from andesitic in the PDC to dacitic in the SLP and PF, indicates that the magma became more acidic with time. This is a common development in a closed magma system with no input of new magma to the magma chamber.

\section{SEDIMENTARY MODEL OF THE DONJE PAZARIŠTE SECTION}

The DP section represents continuous deposition from the early to late Illyrian (Smirčić et al., 2018) and indicates that the depositional marine environment was strongly influenced by volcanism and tectonics. The six facies recognized signify deposition in the following time intervals:

- Flysch-like Facies - Pelsonian or Early Illyrian;

- Carbonate Shale Facies - Early Illyrian;

- Pyroclastic Density Current Facies - Early Illyrian;

- Platy Limestone with Pyroclastites Facies - Early Illyrian;

- Limestone Breccia Facies - Early to Late Illyrian;

- Slumped Limestone with Pyroclastics and Chert Facies Late Illyrian (Smirčić et al., 2018).

The deposition in the DP section began in a relatively deep marine basinal environment. The sandstones and mudstones of the Flysch-like Facies were deposited via turbidity currents and represent the only facies without pyroclastic influence, indicating that deposition commenced without significant volcanic activity affecting this terrain, where terrestrial, shallow and deep marine (pelagic) environments coexisted. The predominance of volcanogenic sandstones indicate chemical and mechanical erosion of igneous or volcaniclastic rocks in the hinterland (Fig. 9A). Siliciclastic debris was possibly derived from the present-day NNW where uplifted blocks were prone to erosion and the material was deposited by turbidity currents in the marine area (as noted by Sokač et al., 1976; Dimitrijević, 1997), thus representing volcanogenic deposits (McPhie et al., 1993). The occurrence of turbidity currents indicate the existence of an un- derwater slope along which material was transported to deeper basinal areas. Detrital material initially accumulated in the shallower parts of the basin and subsequently resedimented down the slope.

Deposition of the Carbonate Shale Facies shows a dominance of carbonate sedimentation, interrupted by short periods of volcanic eruptions (pyroclastic interlayers). A decrease in siliciclastic input indicates reduction in inland erosion and subsequent prevalence of carbonate sedimentation. Slow but continuous shallowing and possible cessation of tectonic activity is inferred. Deposition occurred in a deep marine pelagic environment (shown by thin-shelled bivalves, radiolarians, crinoids and ammonoids - Fig. 9B). The compositional and structural characteristics of the vitriclastic and crystaloclastic tuffs suggest origin of the pyroclastic material in subaerial conditions and deposition through air and water in deeper/pelagic areas.

Onset of the Pyroclastic Density Current Facies indicates intensified volcanic activity shown by pyroclast-rich andesitic explosive eruptions where exclusively pyroclastic layers (crystaloclastic and vitriclastic units) were deposited. The textural and structural characteristics of the pyroclastic units suggest that much of the pyroclastic material (accretionary lapilli, vitriclasts and crystaloclasts) originated on land or in shallow sea by powerful eruptions prior to resedimentation into a deep marine area by relatively brief tractional transport, possibly by turbidity currents. The separation of crystaloclastic from vitriclastic material may have happened during transport in the turbidity current due to rheological and gravitational effects (Fig. 9C).

The occurrence of the Platy Limestone with Pyroclastics Facies indicates prolonged shallowing due to prevalence of carbonate sedimentation with intermittent volcanic activity (Fig. $9 \mathrm{C})$. The chemical composition of the pyroclastic material indicates the same source as in the above-mentioned facies (Smirčić, 2017). Tuff layers in PLP are much thinner than in the PDC Facies. That can be interpreted as a temporary cessation of the volcanic activity, or as reflecting a greater distance to the active volcanic centres. The pyroclastic material was primarily deposited via air-fall processes and resedimented from terrestrial areas. Accretionary lapilli accumulated in some interlayers indicating their subaerial origin, with subsequent sedimentation in a marine environment (Fig. 9C), as interpreted by Marci et al. (1991). The facies characteristics of the interbedded limestones also indicate redepositional processes of shallow water limestones into a deep pelagic environment, indicating disintegration of pre-existing shallow marine areas, possibly a platform environment as described by Krobicki et al. (2014) and Krobicki (2018) for the Jurassic-Cretaceous volcaniclastic rocks of the Carpathians. At the same time, volcanic activity, generating pyroclastic material, had persisted in subaerial conditions, as well as resedimentation of the pyroclasts into deeper marine areas. The co-existance of shallow marine areas and pelagic basins, as well as redepositional processes by gravity currents, imply differentiation into a graben-like depositional environment (with subsiding or uplifting tectonic blocks). The enhanced tectonic activity was probably related to the accompanying volcanism.

The tectonic activity is best witnessed by the occurrence of the Limestone Breccia Facies that interfingers with the PLP. The breccia material was derived from shallow marine areas and redeposited as debris flows in a deeper depositional environment (Fig. 9D). Tectonic movements triggered the redepositional processes. Packstone, wackestone and lithoclastic limestone varieties of the PLP interbedded with the Limestone 
Breccia Facies indicate the redeposition of brecciated limestone fragments into the pelagic realm. Three cycles with $L B$ at the base and PLP above were recognized. The occurrence of each LB indicates the beginning of tectonic activity and terrain uplift whereas the deposition of wackestone with a pelagic biota suggest pelagic conditions for depositon of the LB (Fig. 2). Clasts of shallow marine limestone can be found in the lithoclastic limestones of the PLP and in limestone breccias. The shallow marine limestones could have been formed in adjacent shallow seas. At some point they could have been tectonically uplifted and subsequently eroded, thus forming clasts. These clasts were then transported to the deeper graben/half-graben-like structures, where limestone breccias and lithoclastic limestones of the PLP were deposited.

Each occurrence of PLP starts with the deposition of lithoclastic limestones that are interpreted as the products of deposition from diluted debris flows (Fig. 9D). Sea level oscillations witnessed by the occurrence of wackestones and packestones may have been a consequence of intermittent tectonic movements that caused subsidence in some areas, and uplift in others (Fig. 9D). The uplifted areas were prone to chemical and mechanical erosion (Fig. 9D). In the submarine grabens/halfgrabens, limestone breccias were deposited, and are composed of the material from the uplifted blocks (Fig. 9D), as in other Middle Triassic areas of the External Dinarides (Salopek, 1942; Grimani et al., 1972; Ivanović et al., 1973; Šušnjar et al., 1973; Sokač et al., 1976; Korolija et al., 1979; Bukovac et al., 1983, Šćavničar et al., 1984). The interbedding of the limestone breccias and platy limestones indicates pronounced tectonic subsidence and deposition of slumped and/or brecciated material (Fig. 9C). The tectonic movements, probably related to magmatic and volcanic activity, triggered gravity flows with the material accumulating in the shallower, marginal parts of the basin. These short-lived events were followed by restoration of pelagic conditions, with pelagic limestone varieties deposited together with the pyroclasts. Similar situations have been recorded in areas of the Julian Alps in Slovenia (Celarc et al., 2013), and in other Southern Alpine areas (Farabegoli et al., 1984, 1985; De Zanche et al., 1993; Gianolla et al., 1998; Venturini, 2006; Berra and Carminati, 2010). Celarc et al. (2013) indicated the existence of shallow troughs that were filled with megabreccias (so-called "Uggowitza breccias"), which were sedimented via debris currents or avalanches from topographically higher uplifted blocks. In the DP area, after every breccia interval, crystaloclastic and vitriclastic tuffs occur. That implies that the tectonic activity was closely related to the periods of pyroclastic eruptions. The occurrence of accretionary lapilli in limestone layers overlying breccias, as well as in the pyroclastic layers, seemingly indicates subaerial volcanic eruptions and resedimentation of pyroclastic material (Fig. 9D).

Continuous tectonic activity caused the steepening of the slopes thus resulting in instability and slumping of sediment in grabens or half-grabens (Fig. 9E). The Slumped Limestone with Pyroclastics and Chert Facies, found in the topmost part of the DP section, indicates sedimentation of material on unstable submarine slopes within the pelagic environment. This facies is composed of thin layers of lithoclastic/allodapic limestones, pelagic limestones, pyroclastic deposits and cherts. Resedimented pyroclastic material was constantly transported to the pelagic sedimentary environment, while part of it was sedimented via air-fall from the volcanic cloud. The existence of pronounced underwater topography could have enhanced the channelling of nutrient-rich waters along the slopes to the shallower parts, causing radiolarian blooms, indicated by abundant radiolarians in limestones and cherts (Goričan et al., 2015).
On the uplifted blocks, shallow marine carbonates were deposited as massive algal floatstones and packstones. Pyroclastic material found in contact with or in the vicinity of these limestone types has been interpreted as deposited by subaerial pyroclastic flows (as determined for the Pyroclastic Flow Facies). The Pyroclastic Flow Facies of dacitic composition consists entirely of pyroclasts and indicates volatile-rich eruptions. The facies was determined at two localities $\sim 20 \mathrm{~km}$ apart, but were correlated based on composition, structural and textural characteristics, geochemical properties and surrounding lithologies, thus indicating a distinctive pyroclastic flow deposit. The lithologies from the vicinity of the both exposed PF rocks suggest their shallow marine deposition, and therefore the emplacement of the PF in a shallow marine or even continental environment. Although the stratigraphic position of this facies is still not certain, its geochemical composition can be directly correlated with all of the volcaniclastic facies noted (Smirčić, 2017). Due to constant tectonic activity and sea level oscillations, the deposits of the PF may have been influenced by sea water to various degrees. The oval/elliptical alteration patterns of the macroperlite structure found in the PF from the Top of DP section indicates the hydration of the deposits during the later stage of cooling (Ross and Smith, 1955; Allen, 1988; Yamagashi and Goto, 1992). Since the PF of Brušane section lacks these features it is thought that it was deposited farther from marine influence (Fig. 9D, E).

\section{MIDDLE TRIASSIC SYNTECTONIC SEDIMENTATION IN THE TETHYAN AREA}

Early Triassic environments were similar across the whole Western Tethyan realm, being characterized by shallow marine sedimentation across an extensive epicontinental-like ramp (Hips and Pelikán, 2002; Perri and Farabegoli, 2003; Haas et al., 2004; Kolar-Jurkovšek et al., 2011; Brandner et al., 2012; Aljinović et al., 2018). Pronounced differentiation of the area began in the Anisian with volcanic activity, related to regional tectonic movements (opening of the Tethyan Ocean). Differentiation became more pronounced, with development of subsided (pelagic) and uplifted (shallow marine/subaerially exposed) blocks/areas (Sokač et al., 1976; Sakač, 1992; Dimitrijević, 1997; Balini et al., 2006; Kovács et al., 2011), forming graben, half-graben and simple graben structures across the entire Western Tethyan area (External Dinarides - Belak, 2000; Celarc et al., 2013; Goričan et al., 2015; Southern Alps Bechstädt et al., 1978; Gianolla et al., 1998; and in the Transdanubian range of Hungary; Haas and Budai, 1995; Velledits, 2004, 2006; Budai and Vörös, 2006; Velledits et al., 2011; Péró et al., 2015).

Deeper marine areas were characterized by different sediment types, including volcaniclastic deposits (Sokač et al., 1976; Brusca et al., 1982; Cros and Houel, 1983; Sakač, 1992; De Zanche et al., 1993; Dimitrijević, 1997; Balini et al., 2006; Kovács et al., 2011). After the deposition of shallow marine carbonates of the Gracilis Formation (Bithynian-Pelsonian age) in the Southern Alps, the onset of deeper marine and pelagic conditions took place in oxygen-depleted realms, with the activity of turbidity currents (Kustatscher and Roghi, 2006), similar to those reflected by the FF deposits in the DP section. In Hungary, Anisian basinal environments were filled with marls, tuffs, feldspathic sandstones, resedimented volcaniclastic deposits, radiolarites and limestones with cherts (Velledits, 2000, 2004). The oldest deep marine strata in the External Dinarides com- 


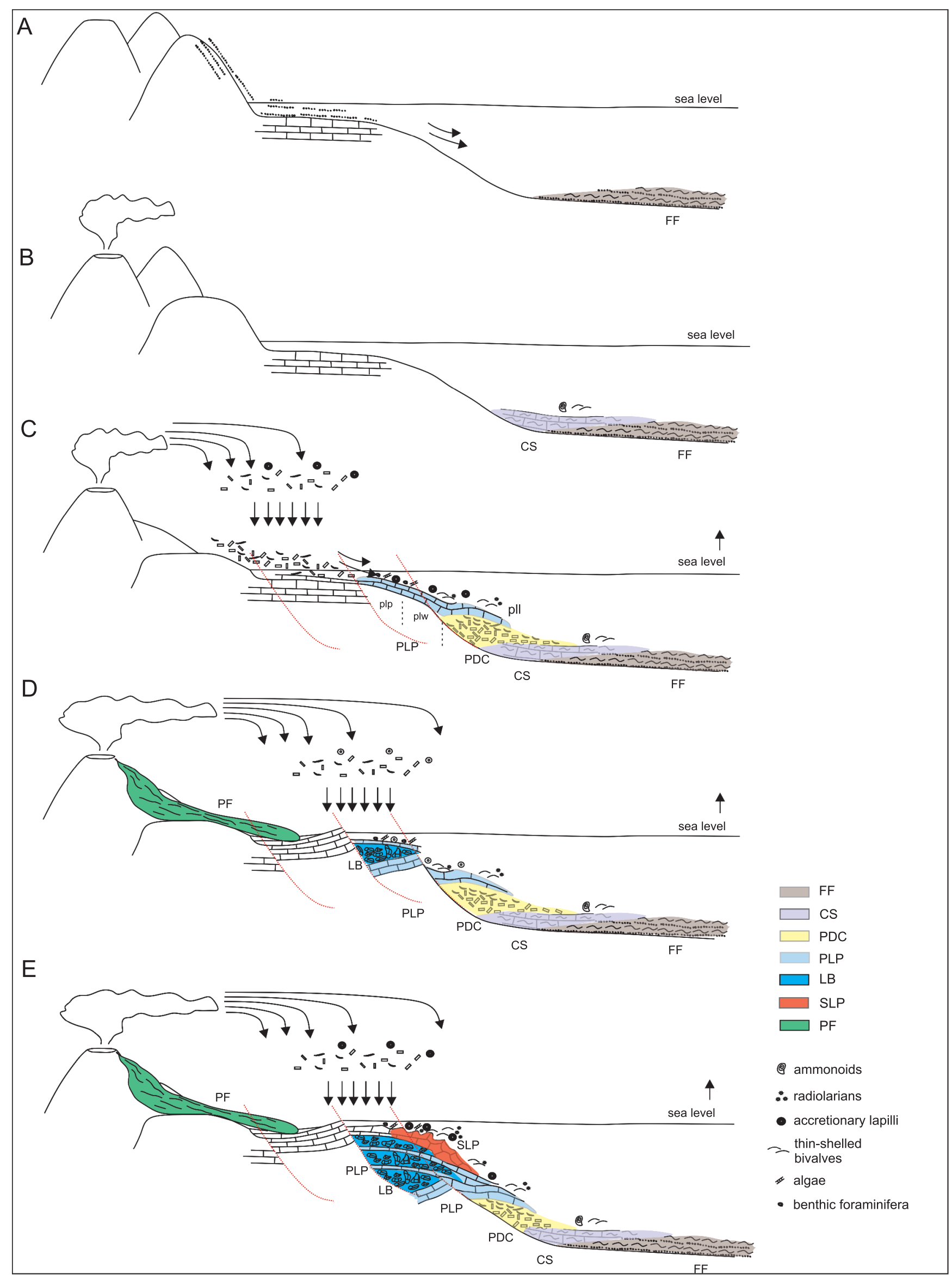


prise the Flysch-like Facies of the DP section (Pelsonian or Lower Illyrian), while at the same time in the rest of the External Dinarides shallow marine limestones and dolostones with occasional volcaniclastic influxes were deposited (Sokač et al., 1976; Pamić, 1984; Vlahović et al., 2005).

In the External Dinarides, shallow marine environments with continuous deposition persisted throughout the Early Triassic but became markedly diverse due to tectonic and volcanic activity in the Anisian. Intense tectonic movements led to the formation of graben/half-graben structures dominated by deeper marine sedimentation and coexisting with nearby subareally exposed (or episodically exposed) areas characterized by the formation of bauxites in the Lika Region, Croatia (Sokač et al., 1976; Marković, 2002; Vlahović et al., 2005), and subaerially emplaced volcanic vents. Lower Triassic deposits were eroded and redeposited in marine environments in the form of the "Otarnik breccias" on Svilaja Mt. (Šćavničar et al., 1984; Marjanac, 2000; Jelaska et al., 2003), while some of the areas remained shallow marine and were characterized by the deposition of algal limestones and dolostones (Herak, 1974; Grgasović and Sokač, 2003; Kóvacs et al., 2011). Deeper marine areas existed at the same time and were filled with cherts and shales (Kóvacs et al., 2011), "flysch deposits" (Sokač et al., 1976; Dimitrijević, 1997), nodular limestones with a pelagic fauna (Kolar-Jurkovšek, 1983; Sakač, 1992; Balini et al., 2006), marls and fine- to coarse-grained siliciclastic deposits (KolarJurkovšek, 1983, 1990; Petek, 1998) and with various volcaniclastic deposits (Kolar-Jurkovšek, 1983, 1990). A similar pattern of deep marine deposits can be traced in the Transdanubian Range of Hungary, where the onset of limestones with chert began in the Anisian (Budai et al., 2003).

In the Western Dolomites, Lower Triassic deposits are found in contact with the Richthofen conglomerates (Brandner and Bechstäldt, 1970), stratigraphically correlated with the Uggowitza breccias (Celarc et al., 2013). The mechanism of formation of the Uggowitza breccias (Celarc et al., 2013) is similar to that of the Limestone Breccia Facies of the DP section (cf. Smirčić et al., 2018). The Late Anisian was characterized by global sea level rise and drowning of carbonate environments (Buser, 1989; Petek, 1998; Buser at al., 2008; Kóvacs et al., 2010, 2011; Sudar et al., 2013). In Hungary also, local coarse-grained clastic deposits appear as the "Szebevisz conglomerates" in contact with Anisian limestones (Vozár et al., 2010), represent similar processes as in the External Dinarides and the southern Alps.
Basinal deposits of nodular limestones with cherts and marls of the Southern Alps, the Ambata Formation, were deposited in the Late Illyrian to Early Ladinian (Preto et al., 2009). The typical Buchenstein Formation or Livinallongo Formation, characterized by nodular limestones with cherts and volcaniclastic strata, were deposited from the Upper Anisian to the Ladinian (Brusca et al., 1982; Cros and Houel, 1983; De Zanche et al., 1993) in the basinal areas of the Southern Alps, thus resembling the PLP of the DP sections.

\section{CONCLUSIONS}

All the localities investigated localities belong to the central part of the Velebit Mts. They are found $15 \mathrm{~km}$ apart and were deposited from the Late Anisian to the Early Ladinian. The facies differ in their genetic characteristics, reflecting available eroded material, the extent of erosion, bathymetric differences, basin morphology, volcanic activity and tectonic activity. On the basis of facies changes observed in the localities investigated, deposition in the Middle Triassic indicates a variety of sedimentary environments, influenced by the constant tectonic movements and almost permanent volcanic activity, as indicated in the surrounding southern coast of the Western Tethyan area.

Lithological correlation of the volcaniclastic deposits in the area investigated is difficult. Nevertheless, the volcaniclastic deposits exhibit the same geochemical characteristics indicating the same major magma source and the same geotectonic suite (Smirčić, 2017).

Deposits of the DP section indicate the existence of several episodes of volcanic/pyroclastic activity on land and in shallow seas. The pyroclastic material was syn-eruptively resedimented into the deeper pelagic basin. The upper part of the DP section indicates cessation of the volcanic activity or moving away of the volcanic centres and the predominance of carbonate sedimentation in a relatively shallow marine area. The occurrence of the Pyroclastic Flow Facies above the DP section described indicates the contemporaneous presence of terrestrial eruptions and inland or shallow marine emplacemant of pyroclastics. The deposition of the rocks recorded in the DP section took place when the tectonic movements occurred and persisted throughout the Late Anisian and Early Ladinian in the wider Western Tethyan region. The occurrence of the limestone breccias indicates periodic tectonic activity (earthquakes), which caused the erosion and

\section{Fig. 9. Sedimentary model of the Donje Pazarište section}

A - deposition of the FF via turbidity currents in the distal part of the basin; there is no evidence of contemporaneous volcanic activity during deposition of FF rocks. B - decrease in the siliciclastic influx enabled the deposition of carbonate-bearing shales in the CS with pelagic fossils (including ammonoids). C - intensified volcanic activity producing pyroclastic material that was primary deposited in the shallower areas of the depositional environment and then resedimented to deeper parts of the basin as pyroclastic density currents. Deposits of the PLP were deposited in slightly shallower parts of the marine basin, likely on the gently inclined slope. The volcanic activity was episodic and pyroclastic material was deposited within the limestone layers. Tectonic activity and rise of sea level caused the cyclic sedimentation manifested as alternations of wackestones (plw), packstones (plp) and lithoclastic limestones (pll). D - the abrupt tectonic activity differentiated the area and caused contemporaneous uplift and subsidence in the terrain. The newly formed grabens/half-grabens were infilled with limestone clasts derived from the uplifted areas. The LB was formed by debris flows or avalanches. A pelagic fauna in the matrix indicates deposition in an open-marine environment. Lithoclastic limestones (pll) were deposited from diluted debris flows that transformed to low-density turbidity currents, thus considered allodapic in origin. After infill of the grabens/half-grabens, limestone sedimentation continued with a constant pyroclastic influence accompanied by marine transgression and deposition of the PLP. Meanwhile, on the shallow marine and subaerially uplifted blocks, pyroclastic flows occurred as a consequence of volcanic activity on land. $\mathbf{E}-$ enhanced tectonic movements formed the unstable submarine slope and provoked the deposition of the Slumped Limestone with Pyroclastics and Cherts Facies 
transport of shallow and deeper marine carbonate particles and finally their deposition as the LB Facies. Probably, the tectonic episodes were contemporaneous with the volcanic eruptions, since the pyroclastic deposits follow each occurrence of limestone breccia. The sedimentary basin was not exceptionally deep but it was probably clearly differentiated from the shallower areas and separated by a pronounced slope. The entire area may be interpreted as graben or half-graben structure. Deeper areas of the basin were filled with the available material relatively quickly, partly because of the extensive erosion, and probably also because the graben and/or half-graben structures were small. Slump textures, found at the top of the DP section, indicate continuation of tectonically unstable conditions influenced by distal explosive eruptions.

The Pyroclastic Flow Facies was formed due to accumulation of pyroclastic material around the volcanic centre and possibly by collapse of a subaerial pyroclastic column. The material was emplaced in a shallow sea, and possibly in continental areas, supports the inference of tectonic activity on land. A pyroclastic flow deposit in the vicinity of Brušane Village, in the foothills of Vinac, resembles the facies recognized at the Top of DP section, $15 \mathrm{~km}$ away. Deposition is interpreted to have been by pyroclastic flow. The only difference is the lack of an oval/nodular alteration pattern in the Brušane pyroclastic deposits, which can be interpreted as an absence of early hydration of the deposits upon emplacement. This suggests that the emplacement of the pyroclastic flow deposits in the DP occurred in a shallow sea, while the same facies was emplaced on land in the Brušane area. The occurrence of intraformational limestone breccias with a red matrix in contact with the Brušane pyroclastic deposits also supports this interpretation.

A common evolution of the magma system, starting with basic and evolving to more acidic character, can be traced in the DP section (the PDC is of andesitic composition, and the younger SLP and PF have dacitic compositions).

Acknowledgements. This study was preformed as part of first author's Ph.D. thesis. The field data was obtained from 2013 until 2016. The investigation was a part of the IGCP 630 project, and was financially supported by the University of Zagreb. We would like to thank Dr. M. Krobicki, Prof. R. Brandner and Dr. B. Celarc for their constructive comments and suggestions during the review which significantly improved the quality of the manuscript.

\section{REFERENCES}

Aljinović, D., Horacek, M., Krystyn, L., Richoz, S., Kolar-Jurkovšek, T., Smirčić, D., Jurkovšek, B., 2018. Western Tethyan epeiric ramp setting in the Early Triassic - an example from the central Dinarides. Journal of Earth Science, 29 806-823.

Allen, J.R.L., 1988. False pyroclastic texture in altered silicic lavas, with implications for volcanic-associated mineralization. Economic Geology, 83: 1424-1446.

Ayres, L.D., Van Wagoner, N.A., Ferreira, W.S., 1991. Voluminous shallow-water emergent phreatomagmatic basaltic volcaniclastic rocks, Proterozoic ( 1886 Ma), Amisk Lake composite volcano, Flin Flon greenstone belt, Canada. SEPM Special Publication, 45: 175-189.

Balini, M., Jurkovšek, B., Kolar-Jurkovšek, T., 2006. New Ladinian ammonoids from Mt. Svilaja (External Dinarides, Croatia). Rivista Italiana di Paleontologia e Stratigrafia, 112: 383-395.

Bechstädt, T., Brandner, R., Mostler, H., Schmidt, K., 1978. Aborted rifting in the Triassic of Eastern and Southern Alps. Neues Jahrbuch für Geologie und Paläontologie Abhandlugen, 156: 157-178.

Belak, M., 2000. Postaja 2: profil Sutina-Zelovo Sutinsko; Kristaloklastični i vitoroklastični tufovi (pietra perde) s proslojcima silicificiranih dolomita, vapnenaca, tufita i rožnjaka (in Croatian). Geološka povijest i strukturna evolucija Vanjskih Dinarida. Vodič ekskurzija 2 (eds. I. Vlahović and R. Biondić): 6-9. Hrvatski geološki kongres, Cavtat-Dubrovnik, Zagreb.

Berra, F., Carminati, E., 2010. Subsidence history from a backstripping analysis of the Permo-Mesozoic succession in the Central Southern Alps (Northern Italy). Basin Research, 22: 952-975.

Boulter, C.A., 1987. Subaqueous deposits of accretionary lapilli: significance for palaeoenvironmental interpretations in Archean greenstone belts. Precambrian Research, 34: 231-246.

Brandner, R., Bechstädt, T., 1970. Carbonatic and clastic sediments correlated to synsedimentary tectonics. Verhandlungen der Geologischen Bundesanstalt, 4: 545-548.
Brandner, R., Horacek, M., Keim, L., 2012. Permian-Triassic-Boundary and Lower Triassic in the Dolomites, Southern Alps (Italy). Journal of Alpine Geology, 54: 379-404.

Brusca, C., Gaetani, M., Jadoul, F., Viel, G., 1982. Ladinian-Carnian palaeogeography and metallogenesis of the Southern Alps. Memoire delle Societa Geologica Italiana, 22: 65-82.

Budai, T., Lelkes, G., Kovács, S., Pálfy, J., Piros, O., Szabó, I., Szente, I., Vörös, A. 2003. The Pelsonian Substage on the Balaton Highland (Middle Triassic, Hungary) (ed. A. Vörös) Geologica Hungarica, Series Palaeontologica, Fasciculus, 55. Geological Institute of Hungary, Budapest.

Budai, T., Vörös, A., 2006. Middle Triassic platform and basin evolution of the Southern Bakony Mountains (Transdanubian range, Hungary). Rivista Italiana di Palaeontologia e Stratigrafia, 112: 359-371.

Bukovac, I., Šušnjar, M., Poljak, M., Čakalo, M., 1983. Osnovna geološka karta SFRJ, 1:100 000, list Črnomelj (in Croatian). Institut za geološka istraživanja Zagreb, Savezni geol. zavod Beograd.

Bull, S.W., Cas, R.A.F., 1991. Depositional controls and characteristics of subaqueous bedded volcaniclastics of the Lower Devonian Snowy River Volcanics. Sedimentary Geology, 74: 189-215.

Buser, S., 1989. Development of the Dinaric and the Julian carbonate platforms and the intermediate Slovenian basin (NW Yugoslavia). Memoire delle Societa Geologica Italalian, 40: 313-320.

Buser, S., Kolar-Jurkovšek, T., Jurkovšek, B., 2008. The Slovenian Basin during the Triassic in the light of conodont data. Bollettino della Societa Geologica Italiana, 127: 257-263.

Castellarin, A., Rossi, P.M.L., 1981. The Southern Alps: an aborted Middle Triassic mountain chain? Eclogae Geologicae Helvetiae, 74: 313-316.

Castellarin, A., Lucchini, F., Rossi, P.L., Selli, L., Simboli, G., 1988. The Middle Triassic magmatic-tectonic arc development in the Southern Alps. Tectonophysics, 146: 79-89.

Celarc, B., Goričan, Š., Kolar-Jurkovšek, T., 2013. Middle Triassic carbonate-platform breakup and formation of small-scale half-grabens (Julian and Kamnik-Savinja Alps, Slovenia). Facies, 59: 583-610. 
Chorowitz, J., 1977. Etude geologique des Dinarides le long de la structure transversale Split-Karlovac (Yugoslavie). Publications de la Société Géologique du Nord, 1: 3-331.

Crisci, C.M., Ferrara, G., Mazzuoli, R., Rossi, P.M., 1984. Geochemical and geochronological data on Triassic volcanism in the Southern Alps of Lombardy (Italy): genetic implications. Geologische Rundschau, 73: 279-292.

Cros, P., Houel, P., 1983. Repartition and palaeogeographic interpretation of volcaniclastic and pelagic sediments of Livinallongo formation. Geologisch-Paläontologische Mitteilungen Innsbruck, 13: 415-452.

Cunningham, J.K., Beard, A.D., 2014. An unusual occurrence of mafic accretionary lapilli in deep-marine volcaniclastics on 'Eua, Tonga: palaeoenvironment and process. Journal of Volcanology and Geothermal Research, 274: 139-151.

Di Capua, A., Groppelli, G., 2016. Application of actualistic models to unravel primary volcanic control on sedimentation (Taveyanne Sandstones, Oligocene Northalpine Foreland Basin). Sedimentary Geology, 336: 147-160.

Di Capua, A., Vezzoli, G., Groppelli, G., 2016. Climatic, tectonic and volcanic controls of sediment supply to an Oligocene Foredeep basin: the Val d'Aveto Formation (Northern Italian Apennines). Sedimentary Geology, 332: 68-84.

De Zanche, V., Gainolla, P., Mietto, P., Siorpaes, C., Vai, P.R., 1993. Triassic sequence stratigraphy in the Dolomites (Italy). Memoire delle Societa Geologica Italiana, 45: 1-27.

Dimitrijević, M.D., 1997. Geology of Yugoslavia (eds. S. Karamata and B. Krstić). Geological institute GEMINI, Belgrad.

Ellis, M., King, G., 1991. Structural control of flank volcanism in continental rifts. Science, 254: 839-842.

Farabegoli, E., Levanti, D., Perri, M.C., Veneri, P., 1984. M. Bivera formation: an atypical Middle Triassic "Rosso Ammonitico" facies from Southern Alps. Giornale di Geologia, 46: 33-46.

Farabegoli, E., Jadoul, F., Martines, M., 1985. Stratigrafia e paleogeografia Anisiche delle Alpi Gulie Occidentali (Alpi Meridionali - Italia) (in Italian). Rivista Italiana di Paleontologia e Stratigrafia, 91: 147-196.

Ferrara, G., Innocenti, F., 1974. Radiometric age evidence of the Triassic thermal event in the Southern Alps. Geologische Rundschau, 63: 572-581.

Fisher, R.V., Schmincke, H.U., 1984. Pyroclastic Rocks. Springer, Berlin.

Flügel, E., 2004. Microfacies of Carbonate Rocks. Analysis, Interpretation and Application. Springer, Berlin, Heidelberg.

Garašić, V., Krkač, M., Lugović, B., Tadej, N., Vrkljan, M. omlija, P., Garapić-Šiftar, G., Majer, V., 2006. Petrological characteristics of Ladinian magmatic rocks from the External Dinarides (Vratnik, Croatia). European Journal of Mineralogy, 18: 44 .

Gianolla, P., De Zanche, V., Mietto, P., 1998. Triassic sequence stratigraphy in the Southern Alps (northern Italy): definition of sequences and basin evolution. SEPM Special Publication, 60: 719-747.

Goričan, Š., Kolar-Jurkovšek, T., Jurkovšek, B., 2015. Palaeoecology of Middle Triassic low diversity radiolarian fauna from Mt. Svilaja (External Dinarides, Croatia) (eds. U.K. Tekin and A. Tuncer): 142-143. 14th Interrad Antalyan international conference on fossils and recent radiolarians.

Grgasović, T., Sokač, B., 2003. Review on fossil dasycladacean associations in the Triassic of Croatia. Acta Micropalaeontologica Sinica, 20: 75-79.

Grimani, I., Šikić, K., Šimunić, An., 1972. Osnovna geološka karta SFRJ, 1:100 000, list Knin (in Croatian). Institut za geološka istraživanja Zagreb, Savezni geol. zavod Beograd.

Haas, J., Budai, T., 1995. Upper Permian-Triassic facies zones in the Transdanubian Range. Rivista Italiana di Paleontologia e Stratigrafia, 110: 249-266.

Haas, J., Kóvacs, S., Krystyn, L., Lein, R., 1995. Significance of Permian-Triassic facies zones in terrain reconstruction in the Alpine - North Panonnian domain. Tectonophysics, 242: 19-40.
Haas, J., Hips, K., Pelikán, P., Zajzon, N., Götz, A.E., Tardi-Filácz, E., 2004. Facies analysis of marine Permian/Triassic boundary sections in Hungary. Acta Geologica Hungarica, 47: 297-340.

Harangi, Sz., Szabó, Cs., Józsa, S., Szoldán, Zs., Árváné Sós, E., Balla, M., Kubovics, I., 1996. Mesozoic igneous suites in Hungary: implications for genesis and tectonic setting in the nortwestern part of Tethys. International Geology Review, 38: 336-360.

Heiken, G.H., 1974. An atlas of volcanic ash. Smithsonian Contribu tions to Earth Sciences, 12: 1-101.

Herak, M., 1974. Paläogeographie und Fazies-Entwicklung während der Trias in den Dinariden Kroatiens. Schriftenreihe Erdwissenschaftlichen Kommissionen Österreichische Akademie der Wissenschaften, 2: 101-106.

Hinterlacher-Ravnik, A., 1965. Magmatske kamni $v$ grödenskih skladih v Sloveniji (in Slovenian). Geologija, 8: 190-224.

Hips, K., Pelikán, P., 2002. Lower Triassic shallow marine succes sion in the Bükk Mountains, NE Hungary. Geologica Carpathica, 53: 351-367.

Hnylko, O., Krobicki, M., Feldman-Olszewska, A., Iwańczuk, J., 2015. Geology of the volcano-sedimentary complex of the Kamyanyi Potik Unit on Chyvchyn Mount (Ukrainian Charpatians): preliminary results. Geological Quarterly, 59 (1): 145-156.

Ivanović, A., Sakač, K., Marković, S., Sokač, B., 1973. Osnovna geološka karta SFRJ, 1:100 000, list Obrovac (in Croatian) Institut za geološka istraživanja Zagreb, Savezni geol. zavod Beograd.

Izett, G.A., 1981. Volcanic ash bed: records of Cenozoic silicic pyroclastic volcanism in Western United States. Journal of Geophysical Research, 86: 10200-10222.

Jackson, T.A., Scott, P.W., Donovan, S.K., Pickerill, R.K., Portell, R.W., Harper, D.A.T., 2008. The colcaniclastic turbidites of the Grand Bay Formation, Carriacou, Grenadines, Lesser Antilles. Caribbean Journal of Science, 44: 116-124.

Jelaska, V., Kolar-Jurkovšek, T., Jurkovšek, B., Gušić, I., 2003. Triassic beds in the basement of the Adriatic-Dinaric carbonate platform of Mt. Svilaja (Croatia). Geologija, 46: 225-230.

Kokelaar, P., 1986. Magma-water interactions in subaqueous and emergant basaltic volcanism. Bulletin of Volcanology, 48: 275-291.

Kolar-Jurkovšek, T., 1983. Middle Triassic conodonts of Slovenia (in Slovenian with English summary). Rudarsko-metalurški Zbornik, 30: 324-364.

Kolar-Jurkovšek, T., 1990. Middle and Upper Triassic microfauna from Slovenia and its biostratigraphic significance (in Slovenian with English summary). Geologija, 33: 21-170.

Kolar-Jurkovšek, T., Jurkovšek, B., Aljinović, D., 2011. Conodont biostratigraphy and lithostratigraphy across the Permian-Triassic boundary at Lukač Section in Western Slovenia. Rivista Italiana di Paleontologia e Stratigrafia, 117: 115-133.

Korolija, B., Živaljević, T., Šimunić, A., 1979. Osnovna geološka karta SFRJ, 1:100 000, list Slunj (in Croatian). Institut za geološka istraživanja Zagreb, Savezni geol. zavod Beograd

Kovács, S., Sudar, M., Karamata, S., Haas, J., Péró, C. Grãdinaru, E., Gawlick, H-J., Gaetani, M., Mello, J., Polák, M., Aljinović, D., Ogorelec, B., Kolar-Jurkovšek, T., Jurkovšek, B., Buser, S., 2010. Triassic environments in the CircumPannonian Region related to the initial Neotethyan rifting stage. In: Variscan and Alpine Terranes of the Circum-Pannonian Region (eds. J. Vozár, F. Ebner, A. Vozárova, J. Haas, S. Kovács, M. Sudar, M. Bielik and C. Péró): 87-156. Slovak Academy of Sciences, Geological Institute, Bratislava

Kovács, S., Sudar, M., Grădinaru, E., Gawlick, H.-J., Karamata S., Haas, J., Péró, C., Gaetani, M., Mello, J., Polák, M., Aljinović, D., Ogorelec, B., Kolar-Jurkovšek, T., Jurkovšek, B., Buser, S., 2011. Triassic evolution of the tectonostratigraphic units of the Circum-Pannonian Region. Jahrbuch der Geologischen Bundesanstalt, 151: 199-280.

Krobicki, M., 2018. Berriasian peperites in the Ukrainian Charpathians - their biostratigraphical control and sedimentological significance. International Meeting around the Jurassic-Creta- 
ceous Boundary - JK2018: 42-44. Muséum d'Histoire naturelle de Genève.

Krobicki, M., Hnylko, O., Feldman-Olszewska, Iwańczuk, J., 2014. Tectono-Stratigraphic Position of the Kaminnyi Potik Unit in the Ukrainian Charpathians and Volcanogenic Rocks of Mt Chyvcyn (eds. R. Rocha, R. Pais, J. Kullberg and J.C. Finney): 533-537. First International Congress on Stratigraphy at the Cutting Edge of Stratigraphy) STRATI 2013. Portugal, Lisboa.

Kustatscher, E., Roghi, G., 2006. Anisian palynomorphs from the Dont formation of the Kühweisenkopf/Monte Prá Della Vacca Section (Norther Italy). Micropalaeontology, 52: 223-244.

Lugović, B., Alther, R., Marjanac, T., Meyer, H.-P., 1998. Orogenic signature in late Cenozoic volcanic rocks from the northern External Dinarides, Croatia. Acta Vulcanologica, 10: 55-65.

Marci, V., Pleteš, G., Bosak, Ž., Šatara, D., 1991. First appearance of accretionary lapilli in Triassic rocks near Donje Pazarište (in Croatian with English summary). Geološki Vjesnik, 43: 113-121.

Marković, S., 2002. Hrvatske mineralne sirovine (in Croatian). Institut za Geološka Istraživanja, Zagreb.

McPhie, J., Doyle, M., Allen, R., 1993. Volcanic textures - a guide to the Interpretation of Textures in Volcanic Rocks. Centre for Ore Deposit and Exploration Studies, University of Tasmania.

Marjanac, T., 2000. Triassic of Dalmatia - evidence of a failed rift (Muć section). Vijesti Hrvatskog Geološkog Društva, 37: 117-126.

Obenholzner, J.H., 1991. Triassic volcanogenic sediments from the Southern Alps (Italy, Austria, Yugoslavia) - a contribution to the "Pietra verde" problem. Sedimentary Geology, 74: 147-171.

Pamić, J., 1984. Triassic magmatism of the Dinarides in Yugoslavia. Tectonophysics, 109: 273-307.

Péró, Cs., Velledits, F., Kovács, S., Blau, J., 2015. The Middle Triassic post-drowning sequence in the Aggtelek Hills (Silica Nappe) and its Tethyan context - first description of the Raming Formation from Hungary. Newsletters on Stratigraphy, 48: 1-22.

Perri, M.C., Farabegoli, E., 2003. Conodonts across the Permian-Triassic boundary in the Southern Alps. Courier Forschungsinstitut Senckenberg, 245: 281-313.

Petek, T., 1998. Scythian and Anisian beds in the quarry near Hrastenice and important finds of Upper Anisian fossils (in Slovenian with English summary). Geologija, 40: 119-151.

Preto, N., Spötl, C., Guaiumi, C., 2009. Evaluation of bulk carbonate $\delta^{13} \mathrm{C}$ data from Triassic hemipelagites and the initial composition of carbonate mud. Sedimentology, 56: 1329-1345.

Ross, C.S., Smith, R.L., 1955. Water and other volatiles in volcanic glasses. American Mineralogist, 40: 1071-1089.

Sakač, K., 1992. Discoptychites oenensis n.sp. and the accompanying ammonite fauna from Anisian deposits in Brotinja, Lika, Central Croatia (in Croatian). Natura Croatica, Hrv. prirodoslov. Muzej Zagreb: 27-40.

Salopek, M., 1942. O gornjem paleozoiku Velebita u okolini Brušana i Baških Oštarija (in Croatian). Rad HAZU, 274: 218-282.

Schmid, S.M., Bernoulli, D., Fügenschuh, B., Matenco, L., Schefer, S., Schuster, R., Tischler, M., Ustaszewski, K., 2008. The Alpine-Carpathian-Dinaridic orogenic system: correlation and evolution of tectonic units. Swiss Journal of Geosciences, 101: 139-183.

Scotese, C.R., 2002. PALAEOMAP web sitewww.scotese.com

Sheridan, M.F., Wohletz, K.H., 1981. Hydrovolcanic explosions: the systematics of waterpyroclast equilibration. Science, $\mathbf{2 1 2}$ 1387-1389.

Shi, L., Feng, Q., Shen, J., Ito, T., Chen, Z.-Q., 2016. Proliferation of the shallow-water radiolarians coinciding with enhanced oceanic productivity in reducing conditions during the Middle Permian, South China: evidence from the Gufeng Formation of western Hubei Province. Palaeogeography, Palaeoclimatology, Palaeoecology, 444: 1-14.

Sigurdsson, H., 2007. Encyclopedia of Volcanoes. Academic Press, San Diego.
Smirčić, D., 2017. Genesis of Middle Triassic volcaniclastic deposits in the External Dinarides (in Croatian with English summary). University of Zagreb.

Smirčić, D., Kolar-Jurkovšek, T., Aljinović, D., Barudžija, U., Jurkovšek, B., Hrvatović, H., 2018. Stratigraphic definition and correlation of Middle Triassic volcaniclastic facies in the External Dinarides: Croatia and Bosnia and Herzegovina. Journal of Earth Science, 29: 864-878.

Soh, W., Taira, A., Ogawa, Y., Taniguchi, H., Pickering, K.T., Stow, D.A.V., 1989. Submarine depositional processes for volcaniclastic sediments in the Mio-Pliocene Misaki Formation, Miura Group, central Japan (eds. A. Taira and F. Masuda): 619-630. Sedimentary facies and the active plate margines. Terra, Tokyo.

Sokač, B., Nikler, L., Velić, I., Mamužić, P., 1974. Osnovna geološka karta SFRJ, list Gospić, 1:100 000 L 33-127 (in Croatian). Institut za geološka istraživanja Zagreb, Savezni geološki zavod, Beograd.

Sokač, B., Šćavničar, B., Velić, I., 1976. Osnovna geološka karta SFRJ 1:100 000 (in Croatian). Tumač za list Gospić L 33-127. Institut za geološka istraživanja Zagreb, Savezni geološki zavod Beograd.

Stampfli, G.M., Borel, G., 2002. A plate tectonic model of Paleozoic and Mesozoic constrained by dynamic plate boundaries and restored synthetic oceanic isochrons. Earth and Planetary Science Letters, 96: 17-33.

Stampfli, G.M., Borel, G., 2003. A revised plate tectonic model for the Western Tethys from Paleozoic to Cretaceous. AAPG International Conference, Barcelona, Spain.

Sudar, M., Gawlick, H.-J., Lein, R., Missoni, S., Kovács, S., Jovanović, D., 2013. Depositional environments, age and facies of Middle Triassic Bulog and Rid formations in the Inner Dinarides (Zlatibor Mountain, SW Serbia): evidence for the Anisian break-up of the Neotethys Ocean. Neues Jahrbuch für Geologie und Paläontologie Abhandlungen, 269: 291-320.

Sulpizio, R., Dellino, P., Doronzo, D.M., Sarocchi, D., 2014. Pyroclastic density currents: state of the art and prespectives. Journal of Volcanology and Geothermal Research, 283: 36-65.

Szoldán, Zs., 1990. Middle Triassic magmatic sequences from different tectonic settings in the Bükk Mts (NE Hungary). Acta Mineralogica-Petrologica, 31: 25-42.

Šćavničar, B., Šćavničar, S., Šušnjara, A., 1984. The volcanic-sedimentary Middle Triassic in the Suvaja brook area (Mt. Svilaja, Outer Dinarides). Acta Geologica, 14: 35-82.

Šušnjar, M., Sokač, B., Bahun, S., Bukovac, J., Nikler, L., Ivanović, A., 1973. Osnovna geološka karta SFRJ, 1:100 000, list Udbina (in Croatian). Institut za geološka istraživanja Zagreb, Savezni geol. zavod Beograd.

Valentine, G.A., Graettinger, A.H., Sonder, I., 2014. Explosion depth for phreatomagmatic eruptions. Geophysical Research Letters, 41: 3045-3051.

Velledits, F., 2000. Evolution of the area from Berva Vally to the Hór Valley in the Middle-Upper Triassic. Földtani Közlöny, 130: 47-93.

Velledits, F., 2004. Anisian terrestrial sediments in the Bükk Mountains (NE Hungary) and their role in the Triassic rifting of the Vadar-Meliata branch of Neo-Tethys Ocean. Rivista Italiana di Paleontologia e Stratigrafia, 110: 659-679.

Velledits, F., 2006. Evolution of Bükk Mountains (NE Hungary) during the Middle-Late Triassic asymmetric rifting of the Vadar-Meliata branch of the Neotethys Ocean. International Journal of Earth Science, 95: 395-412.

Velledits, F., 2009. Tectonic control on the evolution of the Middle Triassic platforms in the Alpine-Carpathian-Dinaric Region (differences in the evolution of two opposite shelves of the Neotethys Ocean). In: Geomorphology and Plate Tectonics (eds. D.M. Ferrari and A.R. Guiseppi): 359-375. Nova Science, New York.

Velledits, F., Péró, C., Blau J., Senowbari-Daryan, B., Kovács, S., Piros, O., Pocsai, T., Szügyi-Simon, H., Dumitrică, P., 
Pálfy, J., 2011. The Oldest Triassic Platform margin reef from the Alpine-Carpathian Triassic, Aggtelek, NE Hungary. Rivista Italiana di Paleontologia e Stratigrafia, 177: 221-268.

Velledits, F., Lein, R., Krystyn, L., Péró, Cs., Piros, O., Blau, J., 2017. A Reiflingi esemény hatása az Északi-Mészk alpok és az Aggteleki-hegység középs -triász fejl désére (in Hungarian) Földtani Közlöny, 147: 3-24.

Venturini, C., 2006. Evoluzione geologica delle Alpi Carniche (in Italian). Pubblicazioni del Museo Friulano di Storia Naturale, 48.

Vishnevskaya, V., 1996. Development of Palaeozoic-Mesozoic Radiolaria in the Northwestern Pacific Rim. Marine Micropaleontology, 30: 79-95.

Vlahović, I., Tišljar, J., Velić, I., Matičec, D., 2005. Evolution of Adriatic Carbonate Platform: Palaeogeography, main events and depositional dynamics. Palaeogeography, Palaeoclimatology, Palaeoecology, 220: 333-360.

Vozár, J., Ebner, F., Vozárová, A., Haas, J., Kovács, S., Sudar, M., Bielik, M., Péró, C., 2010. Variscan and Alpine Terraines of the
Circum-Pannonian Region. Slovak Academy of Sciences, Geological Institute, Bratislava.

Wang, T., Li, G., Aitchison, J.C., Ding, L., Sheng, J., 2019. Evolution of mid-Cretaceous radiolarians in response to oceanic anoxic events in the eastern Tethys (southern Tibet, China). Palaeogeography, Palaeoclimatology, Palaeoecology, 536: 109369.

Wohletz, K.H., 1983. Mechanisms of hydrovolcanic pyroclast formation: grain size, scanning electron microscopy, and experimental studies. Journal of Volcanology and Geothermal Research, 17: 31-63.

Wohletz, K.H., 1986. Explosive magma-water interactions: thermodynamics, explosion mechanisms, and field studies. Bulletin of Volcanology, 48: 245-264.

Yamagashi, H., Goto, Y., 1992. Cooling joints of subaqueous rhyolite lavas at Kuriowa, Yaumo, southern Hokkaido, Japan. Bulletin of Volcanological Society of Japan, 37: 205-207. 